link online: http://jurnal.dpr.go.id/index.php/aspirasi/index

\title{
Analisis Perilaku Pemilahan Sampah di Kota Surabaya
}

\author{
The Analysis of Waste Sorting Behavior in Surabaya
}

\section{Elga Andina}

elga.andina@dpr.go.id

Pusat Penelitian Badan Keahlian DPR RI

Jl. Gatot Subroto Senayan Jakarta

\begin{abstract}
Naskah diterima: 30 September 2019 | Naskah direvisi: 21 November 2019 | Naskah diterbitkan: 29 Desember 2019
\end{abstract}
\begin{abstract}
Surabaya is one of the cities with the highest waste generation. Waste sorting from its source is the key to manage waste effectively. This qualitative research used a study case approach to figure out trash sorting behavior in Surabaya. Data are gathered from an interview with Surabaya's Department of Cleanliness and Green Open Space, Non-Government Agency related to waste, and Surabaya's Main Waste Bank. Observation is conducted in Pusat Daur Ulang Jambangan, city parks and boulevards to see how people sort the waste in public areas. Even though Surabaya has a world-recognized hygiene program, it doesn't necessarily make its people care about cleanliness and sorting waste. The knowledge doesn't always lead to behavior. Waste sorting behavior is still related to the physical and social conditions of the community (external factors). Thus, to develop the sorting behavior requires three strategies: (1) strengthening policy; (2) providing ergonomic facilities; and (3) community involvement in changing behavior.
\end{abstract}

Keywords:waste sorting, behavior, Surabaya

Abstrak: Surabaya merupakan salah satu kota dengan timbulan sampah terbesar. Pemilahan
sampah dari sumber merupakan kunci untuk mengelola sampah dengan efektif. Penelitian
kualitatif ini bercorak studi kasus bertujuan mengetahui perilaku pemilahan sampah di Kota
Surabaya. Data diperoleh melalui wawancara dengan Dinas Kebersihan dan Ruang Terbuka Hijau
Kota Surabaya, LSM Pemerhati Sampah, Bank Sampah Induk Surabaya. Pengamatan dilakukan
di Pusat Daur Ulang Jambangan, taman kota dan jalan-jalan untuk mengetahui bagaimana
masyarakat memilah sampah di tempat umum. Meskipun Surabaya memiliki program kebersihan
yang diakui dunia, tidak serta merta menjadikan masyarakatnya peduli kebersihan dan melakukan
pemilahan sampah. Pengetahuan tidak selalu menghasilkan perilaku pemilahan sampah. Perilaku
pemilahan sampah masih berkaitan dengan kondisi lingkungan fisik dan sosial masyarakat (faktor
eksternal). Oleh karena itu, perilaku pemilahan sampah perlu dibentuk dengan 3 strategi: (1)
penguatan kebijakan; (2) penyediaan sarana yang ergonomis; dan (3) pelibatan masyarakat dalam
mengubah perilaku.

Kata kunci: pemilahan sampah, perilaku, Surabaya 


\section{Pendahuluan}

Pertumbuhan ekonomi dirasakan di Indonesia seiringan dengan peningkatan timbulan sampah. Untuk mengelola permasalahan sampah yang semakin mengganggu, pemerintah telah mengeluarkan Peraturan Pemerintah Nomor 97 Tahun 2017 tentang Kebijakan dan Strategi Nasional Pengelolaan Sampah Rumah Tangga dan Sampah Sejenis Sampah Rumah Tangga (Jakstranas). Kebijakan ini bertumpu pada dua sektor yaitu pengurangan dan penanganan sampah rumah tangga dan sampah sejenis sampah rumah tangga. Ditargetkan pada tahun 2025 kita dapat mengurangi $30 \%$ sampah rumah tangga dan menangani 70\% sampah rumah tangga.

Bank Dunia (2018) memperkirakan 85.000 ton sampah dihasilkan setiap hari di Indonesia. Jika diasumsikan kenaikan 150.000 ton dihasilkan per hari pada tahun 2025 (KLHK, 2019: 8) maka jumlah kenaikan ini mencapai 76\% hanya dalam kurun waktu 10 tahun. Dari jumlah tersebut, sekitar $40 \%$ sampah padat dihasilkan oleh rumah tangga, sisanya dari pasar (20\%), jalan raya (95), sarana publik (9\%), perkantoran $(8 \%)$, dan industri $(6 \%)$. Kondisi ini menuntut upaya penanganan sampah harus digenjot untuk mengimbangi kenaikan tahunan timbulan sampah, terutama di perkotaan yang laju pertumbuhannya terus meroket.

Pengurangan sampah harus dilakukan dengan mengurangi timbulan dari sumber. Akan tetapi, pertumbuhan timbulan sampah melebihi kemampuan kita untuk mengelolanya. Pola pengelolaan sampah di Indonesia masih menitikberatkan pada pembuangan sampah secara open dumping (Prasetiawan, 2014: 47), yang menyebabkan pertumbuhan timbulan sangat pesat. Di tahun 2018, 55,56 TPA beroperasi secara open dumping, dan $44,4 \%$ sisanya bersifat non-open dumping (KLHK, 2019: 12). Jika dibandingkan dengan negara maju, kita masih belum mengeksplorasi upaya pembuangan sampah dalam bentuk komposting, daur ulang, dan insinerasi. Upaya ini perlu dipertimbangkan mengingat semakin meningkatnya timbulan sampah dari tahun ke tahun. Jumlah timbulan sampah di tahun 2025 diproyeksikan mencapai 70.8 juta ton (KLHK, 2019).
Dalam hal pengelolaan sampah, Surabaya dianggap dapat menjadi teladan. Terbukti pada tahun 2017, United Nation Environment Program (Badan Perserikatan Bangsa-Bangsa untuk program lingkungan) menetapkan Kota Surabaya bersama Kota Mannheim (Jerman) dan Zhejiang Province (China) sebagai tiga kota terbaik dunia untuk kategori "Global Green City” dalam acara Forum Global tentang Pemukiman dan Kota Berkelanjutan (Rukmananda, 2017). Surabaya juga mendapatkan apresiasi dari United Cities and Local Governments (UCLG) Committee atas program penghijauan dan pengurangan sampah, sehingga mulai tahun 2019 walikota Tri Rismaharini didaulat menjadi presiden UCLG untuk kawasan Asia Pasifik. Saat ini kota Surabaya telah menjadi benchmark bagi pengelolaan sampah di Indonesia, meskipun hanya memiliki anggaran sebesar Rp16.668.000.000 yang meliputi Rp119.245.800.879 untuk pembayaran operasional pengolahan sampah dan Rp41.397.202.610 untuk operasional pengangkutan sampah (RKPD Kota Surabaya, 2019).

Namun begitu, BPS (2018) menetapkan nilai Indeks Perilaku Ketidakpedulian Lingkungan Hidup (IPKLH) Provinsi Jawa Timur dalam hal pengelolaan sampah pada angka 0.75 , yang paling tinggi dibandingkan provinsi lain di Pulau Jawa-Bali. Menurut data BPS (2018) pula, masyarakat di Pulau Papua, Kalimantan, Jawa-Bali dan Sumatera memiliki indeks ketidakpedulian lingkungan yang lebih tinggi daripada nilai indeks rata-rata nasional. Di Pulau Jawa, perilaku ketidakpedulian lebih didominasi mengenai transportasi pribadi dan pengelolaan sampah (BPS, 2018: 32). Artinya, mereka masih kurang perhatian terhadap cara-cara pengelolaan sampah yang mengarah pada upaya pemeliharaan lingkungan.

Nilai ini menjadimenarik karena bertentangan dengan kesimpulan BPS (2018: 38) yang menyatakan bahwa semakin baik kondisi sosial ekonomi suatu wilayah maka perilaku kepedulian pengelolaan sampahnya semakin baik. Ternyata kelompok provinsi dengan IPM dan PDRB perkapita tinggi cenderung berkelompok pada nilai IPKLH rendah. Pada tahun 2018 IPM semua 
kabupaten dan kota di Provinsi Jawa Timur tidak ada yang berkategori rendah (BPS, 2019). Kota Surabaya bahkan mendapat predikat sangat tinggi. Sementara laju pertumbuhan ekonominya terus melampaui Jawa Timur dan nasional.

\section{Tabel 1. Persentase Pertumbuhan Ekonomi Kota Surabaya, Jawa Timur dan Nasional,} Tahun 2015-2017

\begin{tabular}{lccc}
\hline $\begin{array}{l}\text { Pertumbuhan } \\
\text { Ekonomi }\end{array}$ & $\mathbf{2 0 1 5}$ & $\mathbf{2 0 1 6}$ & $\mathbf{2 0 1 7}$ \\
\hline Surabaya & 5,97 & 6,00 & 6,10 \\
Jawa Timur & 5,44 & 5,57 & 5,54 \\
Nasional & 4,88 & 5,03 & 5,07 \\
\hline
\end{tabular}

Sumber: RKPD Kota Surabaya Tahun 2019

Pertumbuhan ekonomi Surabaya yang terus meningkat menyebabkan kota ini menjadi sebagai salah satu dari lima kota dengan timbulan sampah terbanyak di Indonesia. Pada tahun 2017 Surabaya menghasilkan 2.913,18 ton sampah per hari, sedangkan di tahun 2018 jumlahnya menjadi 2.164,4 ton/hari (DKRTH, 2018: 22). Data Sistem Informasi Pengelolaan Sampah Nasional mencatat 1.477 ton sampah ditimbun per hari di Tempat Pembuangan Akhir (TPA) Benowo. Dari jumlah tersebut sekitar 54,31\% dari sampah yang masuk ke TPA Benowo merupakan sampah organik (Effendi, 2017).

Tabel 2. Persentase Komposisi Sampah Kota Surabaya, Tahun 2017-2018

\begin{tabular}{lc}
\hline Jenis & Persentase \\
\hline Sisa makanan & 54,31 \\
Kayu ranting daun & 1,61 \\
Kertas & 14,63 \\
Plastik & 19,44 \\
Logam & 0,48 \\
Kain tekstil & 1,47 \\
Karet kulit & 2,33 \\
Kaca & 1,12 \\
Lainnya & 4,61 \\
\hline
\end{tabular}

Sumber: Kementerian Lingkungan Hidup dan Kehutanan, 2019

Jumlah sampah yang berakhir di TPA sebenarnya bisa dikurangi jika sampah telah dipilah untuk dapat diproses. Sampah organik

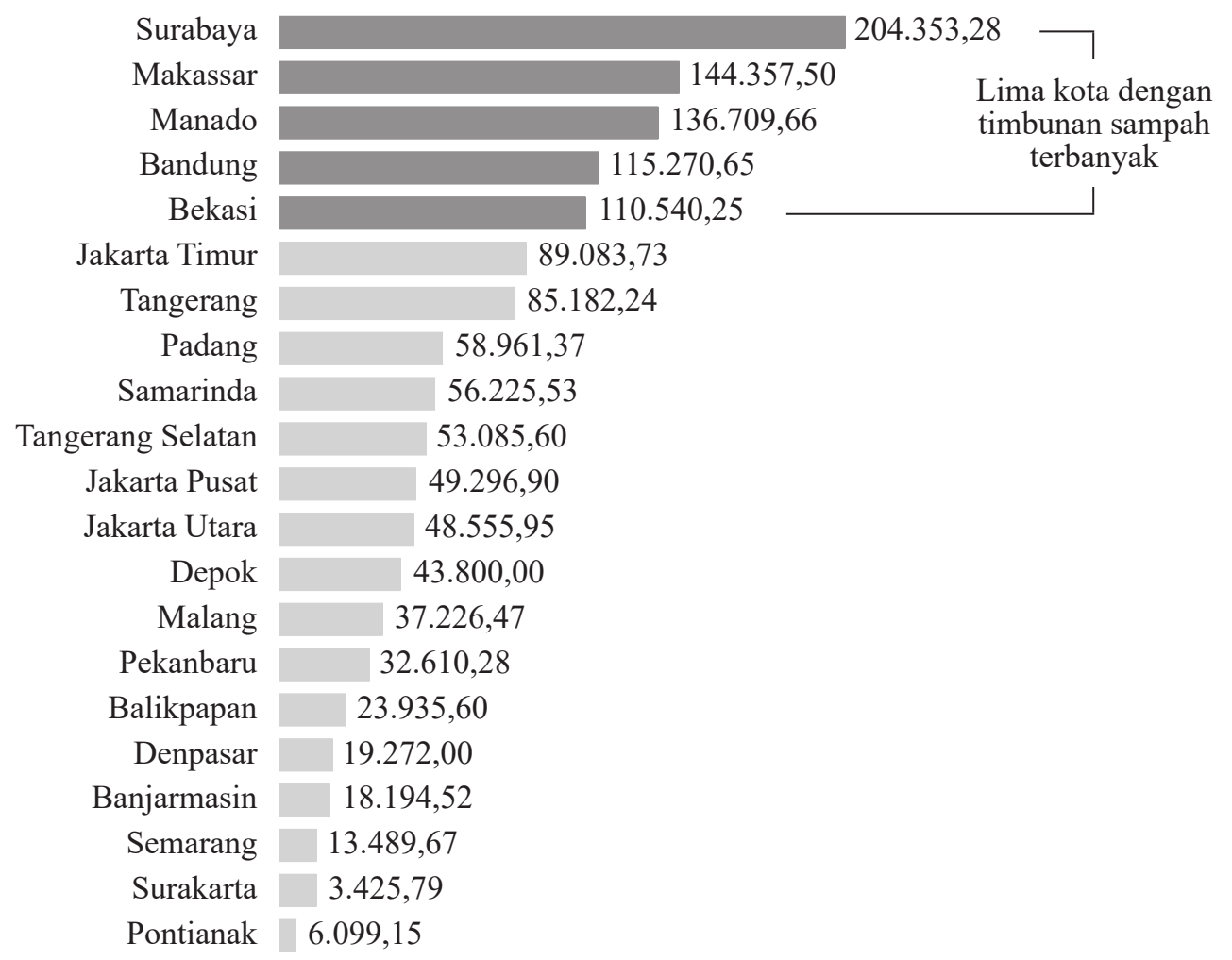

Grafik 1. Volume Timbunan Sampah Plastik di Sejumlah Kota $\left(m^{3}\right)$, Tahun 2015 Sumber: Litbang Kompas diolah dari Dirjen Pengelolaan Sampah Limbah dan Bahan Berbahaya Beracun KLHK 
dapat ditangani dengan komposting, sementara proses daur ulang dapat dilakukan pada sampah plastik yang sejenis agar dapat dileburkan menjadi produk baru yang bernilai. Proses insinerasi pun lebih efisien dilakukan pada sampah kering dibandingkan jika sampah bercampur antara kering dan basah. Pemilahan sampah yang tidak benar meningkatkan biaya program pendaurulangan karena bertambahnya waktu dan tenaga yang dibutuhkan untuk memilah kembali sampah (Bohm, Folz, Kinnaman, \& Podolski, 2010). Oleh karena itu, kegiatan pemilahan sampah, terutama di sumber (masyarakat) merupakan pondasi penanganan sampah yang efektif.

Mengingat pentingnya kegiatan pemilahan sampah ini, maka penelitian ini ingin memfokuskan analisis pada perilaku pemilahan sampah di Kota Surabaya. Keberhasilan Surabaya mencapai berbagai penghargaan tidak mungkin dilakukan tanpa partisipasi masyarakat. Jika masyarakat dapat menangani sampah di lingkungannya, maka dapat mengurangi jumlah yang harus dikelola oleh pemerintah.

Jenis penelitian ini adalah kualitatif dengan rancangan studi kasus. Penelitian ini memberikan perhatian pada fenomena individu dan komunitas terkait pemilahan sampah. Dengan menggunakan konsep triangulasi, pengumpulan data diperoleh melalui wawancara dengan Dinas Kebersihan dan Ruang Terbuka Hijau Kota Surabaya, LSM Pemerhati Sampah, Bank Sampah; observasi pengelolaan sampah di ruang publik; didukung informasi dari laporan resmi dan berita media massa. Wawancara dilakukan secara terbuka dimulai dengan pertanyaan, "Bagaimana perilaku pemilahan sampah di Surabaya?" Pengambilan data dilakukan dalam kegiatan penelitian Bidang Kesejahteraan Sosial di Pusat Penelitian Badan Keahlian DPR RI tentang Kebijakan Pembatasan Sampah Plastik Sekali Pakai dan Implikasinya terhadap Industri dan Masyarakat (Studi di Kota Bandung dan Kota Surabaya) pada Maret 2019.

Observasi dilakukan secara random di sarana publik yaitu lingkungan kantor pemerintah kota Surabaya di Jalan Taman Surya; Taman Bungkul dan sekitar Jalan Raya Darmo; Taman Harmoni, Keputih; serta Kampung Jambangan. Data wawancara dan FGD dicatat dalam bentuk transkrip, untuk kemudian dideskripsikan dan disajikan dalam bentuk teknik penjelasan (explanatory-building).

\section{Jenis Sampah}

Secara umum kita sering mendengar adanya sampah organik dan anorganik yang dibedakan berdasarkan sifat dan struktur kimianya. Sampah organik merupakan sampah yang mudah membusuk atau terurai secara alamiah/biologis dibantu oleh bakteri (Kholida et al., 2019: 8), meliputi sisa tumbuhan, hewan, dan sisa makanan. Sampah organik juga biasa disebut sebagai sampah basah. Biasanya sampah ini berasal dari rumah tangga yang dapat diproses kembali menjadi pupuk kompos.

Sampah anorganik merupakan sampah yang sulit terurai secara biologis dan proses penghancurannya membutuhkan penanganan di tempat khusus (Lestari \& Riyanto, 2018; Loka Pengelolaan SD Pesisir \& Laut Sorong, 2018). Contoh dari sampah anorganik, misalnya plastik, kaleng, pembungkus makanan, kertas, dan stirofoam. Sampah jenis ini juga biasa disebut sampah kering dan dapat diolah menjadi produk lain, misalnya kerajinan tangan hiasan bunga dari bungkus kopi atau tas dari bungkus deterjen. Banyak produk anorganik diciptakan untuk memberikan kemudahan dan meningkatkan kenyamanan bagi manusia. Namun, setelah pemakaian produk tersebut menyebabkan timbulan sampah anorganik yang terus meningkat, sebagaimana yang digambarkan dalam Tabel 3.

Tabel 3. Persentase Komposisi Sampah Indonesia Berdasarkan Data Adipura

\begin{tabular}{lccc}
\hline Jenis sampah & $\mathbf{2 0 1 3}$ & $\mathbf{2 0 1 6}$ & $\mathbf{2 0 1 8}$ \\
\hline Sampah organik & 60 & 57 & 57 \\
Sampah plastik & 14 & 16 & 15 \\
\hline
\end{tabular}

Sumber: Paparan Menteri LHK dalam rapat kerja Menteri LHK dengan Komisi VII DPR RI, 2019

Negara mengklasifikasikan sampah dalam Undang Undang Nomor 18 Tahun 2008 tentang Pengelolaan Sampah (UU Pengelolaan Sampah), di mana dikenal ada tiga jenis sampah: (1) sampah rumah tangga, (2) sampah sejenis sampah rumah tangga; dan (3) sampah spesifik. 
Sampah rumah tangga merupakan sampah yang dihasilkan dari kegiatan sehari-hari dalam rumah tangga, biasanya berupa sampah makanan, kotak makanan, plastik, kain, kulit, sampah kebun, kayu, kaca, besi, debu, dan sampah khusus (seperti barang tebal, barang elektronik, barang putih-barang elektronik ukuran besar seperti kulkas-, alat pembersih), sampah elektronik (komputer, telepon, televisi) (Hoornweg \& Bhada-Tata, 2012: 7). Sementara sampah sejenis sampah rumah tangga dijelaskan dalam UU Pengelolaan Sampah ini sebagai sampah yang berasal dari kawasan komersial, kawasan industri, kawasan khusus, fasilitas sosial, fasilitas umum, dan atau fasilitas lainnya. Dengan kata lain ini merupakan klasifikasi bagi sampah yang dihasilkan di luar rumah. Untuk sampah spesifik sendiri terdiri dari: (1) sampah yang mengandung bahan berbahaya dan beracun; (2) sampah yang mengandung limbah bahan berbahaya dan beracun; (3) sampah yang timbul akibat bencana; (4) puing bongkaran bangunan; (5) sampah yang secara teknologi belum dapat diolah; dan/atau (6) sampah yang timbul secara tidak periodik.

Klasifikasi sampah ini dijelaskan lebih lanjut dalam Peraturan Menteri Pekerjaan Umum Nomor 3 Tahun 2013 tentang Penyelenggaraan Prasarana dan Sarana Persampahan dalam Penanganan Sampah Rumah Tangga dan Sampah Sejenis Sampah Rumah Tangga. Pertama, sampah yang mengandung bahan berbahaya dan beracun serta limbah bahan berbahaya dan beracun; antara lain kemasan obat serangga, kemasan oli, kemasan obat-obatan, obat-obatan kadaluarsa, peralatan listrik, dan peralatan elektronik rumah tangga. Kedua, sampah yang mudah terurai, yaitu sampah yang berasal dari tumbuhan, hewan, dan/ atau bagian-bagiannya yang dapat terurai oleh makhluk hidup lainnya dan/atau mikroorganisme seperti sampah makanan dan serasah. Ketiga, Sampah yang dapat digunakan kembali: yang dapat dimanfaatkan kembali tanpa melalui proses pengolahan antara lain kertas kardus, botol minuman, dan kaleng. Keempat, sampah yang dapat didaur ulang, merupakan sampah yang dapat dimanfaatkan kembali setelah melalui proses pengolahan antara lain sisa kain, plastik, kertas, dan kaca. Kelima, sampah lainnya yang berupa residu. Residu adalah sampah yang tidak dapat diolah dengan pemadatan, pengomposan, daur ulang materi dan/atau daur ulang energi.

\section{Pengaturan Pemilahan Sampah}

Setiap jenis sampah ditangani dengan cara yang berbeda, sehingga perlu dilakukan pemilahan. Pemilahan sampah diatur dalam Peraturan Pemerintah Nomor 81 Tahun 2012 tentang Pengelolaan Sampah Rumah Tangga Dan Sampah Sejenis Sampah Rumah Tangga yang dilakukan melalui kegiatan pengelompokan sampah menjadi paling sedikit 5 (lima) jenis sampah yang terdiri atas: (1) sampah yang mengandung bahan berbahaya dan beracun serta limbah bahan berbahaya dan beracun; (2) sampah yang mudah terurai; (3) sampah yang dapat digunakan kembali; (4) sampah yang dapat didaur ulang; dan (5) sampah lainnya.

Untuk mendorong pemilahan sampah, UU Pengelolaan Sampah menegaskan kewajiban dibangunnya fasilitas pemilahan sampah di kawasan permukiman, kawasan komersial, kawasan industri, kawasan khusus, fasilitas umum, fasilitas sosial, dan fasilitas lainnya. Dengan kata lain, tempat sampah yang disediakan tidak boleh berbentuk tunggal, tapi telah terpilah agar masyarakat dapat membuang sampah yang tepat pada tempat yang sesuai. Ditegaskan pula dalam Pasal 17 Peraturan Pemerintah Nomor 81 Tahun 2012 tentang Pengelolaan Sampah Rumah Tangga dan Sampah Sejenis Sampah Rumah Tangga, bahwa Pemerintah Kabupaten/ Kota menyediakan sarana pemilahan sampah untuk paling sedikit 5 (lima) kelompok sampah. Peraturan ini mengharuskan Pemerintah Kabupaten/Kota menyediakan fasilitas pemilahan sampah paling lama:

1) Tiga tahun sejak PP $81 / 2012$ berlaku untuk penyediaan fasilitas pemilahan untuk tiga jenis sampah (sampah yang mudah terurai, sampah yang dapat didaur ulang, dan sampah lainnya) dilakukan paling lama.

2) Lima tahun sejak PP $81 / 2012$ berlaku untuk penyediaan fasilitas pemilahan untuk lima jenis sampah (sampah dan bahan berbahaya dan beracun/B3, sampah yang mudah terurai, 
sampah yang dapat digunakan kembali, sampah yang dapat didaur ulang, dan sampah lainnya).

Berdasarkan kedua peraturan di atas, disusunlah Peraturan Daerah Kota Surabaya Nomor 5 Tahun 2014 tentang pengelolaan sampah dan kebersihan di kota Surabaya dan Peraturan Walikota Surabaya Nomor 64 Tahun 2018 tentang Kebijakan Strategi Pengelolaan Sampah Rumah Tangga dan Sampah Sejenis Sampah Rumah Tangga. Dengan aturan tersebut, pemilahan sampah harus dilakukan oleh (1) setiap orang pada sumbernya; (2) pengelola kawasan permukiman, kawasan komersial, kawasan industri, kawasan khusus, fasilitas umum, fasilitas sosial, dan fasilitas lainnya; dan (3) pemerintah daerah. Di sini pemerintah daerah dituntut untuk menyediakan sarana pemilahan sampah skala daerah. Sarana tersebut harus memenuhi persyaratan:

1) Jumlah sarana sesuai jenis pengelompokan sampah yaitu: (1) sampah yang mengandung bahan berbahaya dan beracun, serta limbah bahan berbahaya dan beracun; (2) sampah yang mudah terurai; (3) sampah yang dapat digunakan kembali; (4) sampah yang dapat didaur ulang; dan (5) sampah lainnya.

2) Diberi label atau tanda.

3) Bahan, bentuk, dan warna wadah.

\section{Kepedulian Pemilahan Sampah}

Pada tahun 1976, O'Riordan berasumsi bahwa manusia merupakan makhluk bernalar, yang jika diberikan informasi relevan mengenai lingkungan akan mengubah sikap dan membentuk perilaku tertentu (Burn, 1991). Namun, asumsi tersebut ternyata keliru. Bahkan ketika orang mengetahui mengenai perilaku ramah lingkungan, belum tentu ia dapat mempraktikkannya (Cone \& Hayes, 1980; Heberlein, 1976, dalam Burn, 1991: 613). Analogi ini juga berlaku dalam pemilahan sampah. Penelitian Zakianis dan Djaja (2017: 3) menemukan bahwa perilaku pemilahan sampah berkaitan dengan kepedulian lingkungan. Kepedulian lingkungan dapat mendorong individu untuk memilah dan mendaur ulang sampah (Zakianis \& Djaja, 2017: 3). Menurut mereka, kepedulian lingkungan dapat ditingkatkan dengan konseling manajemen sampah yang akan memberi individu peningkatan kesadaran, pengetahuan, keterampilan, nilai, dan pengalaman untuk menyelesaikan permasalahan lingkungan termasuk manajemen sampah (Zakianis \& Djaja, 2017: 3). Kesimpulan ini selaras dengan penelitian Anifa, Anward dan Erlyani (2017: 101) di sekolah yang menemukan live and symbolic modeling dari guru dapat meningkatkan perilaku siswa membuang sampah sesuai warna tempat sampah. Hal ini membuktikan bahwa perilaku memilah sampah dapat diajarkan dan dibiasakan.

Secara khusus Zakianis dan Djaja (2017: 3) menyimpulkan masyarakat ekonomi lemah di Surabaya cenderung memilah dan mendaur ulang sampah, karena adanya insentif ekonomi dari kegiatan tersebut. Sebaliknya masyarakat ekonomi tinggi tidak memiliki waktu untuk memilah dan mendaur ulang sampahnya, apalagi jika memiliki ruang yang luas mereka dapat menyimpan sampah sendiri (Bernstad, 2015, dalam Zakianis \& Djaja, 2017: 3).

Pemilahan sampah di sumber membantu mengklasifikasikan sampah yang dapat dimanfaatkan, diolah lagi, dan yang tidak bisa dimanfaatkan. Pemilahan di sumber (rumah tangga) akan memberikan kesempatan bagi masyarakat untuk mendapatkan sampah yang bernilai, misalnya botol atau kardus. Masyarakat dapat memisahkan sampah yang masih bisa digunakan dan hanya membuang yang tidak dapat diolah. Sementara itu, untuk mengolah sampah organik Jika sampah organik yang bercampur dengan sampah anorganik akan sulit diuraikan dan dijadikan kompos. Dalam penanganan sampah organik misalnya dengan metode takakura, bentuk dan jenis sampah organik yang dipotong kecil akan mempercepat proses pengomposan. Demikian juga pada sampah anorganik yang sudah dikelompokkan akan memudahkan untuk didaur ulang, karena dalam proses daur ulang semakin sejenis materialnya maka semakin baik hasil keluarannya. Sampah yang tercampur juga akan membuat proses selanjutnya tertunda sehingga menimbulkan bau tidak sedap, mengundang vektor penyakit, dan merusak pemandangan. Oleh karena itu, menurut Kementerian Pekerjaan Umum (2010) pemilahan 
sampah memiliki beberapa manfaat, antara lain: (1) Barang yang masih bisa dimanfaatkan tidak terbuang sia-sia; (2) Memberikan penghasilan tambahan bagi masyarakat dan para pelaku daur ulang sampah dengan menjual sampah yang memiliki nilai; (3) Dapat mengurangi volume sampah yang diangkut ke TPA; (4) Menjaga kesehatan dan keselamatan petugas pengelola sampah; dan (5) Mengurangi pencemaran dan menjaga kebersihan lingkungan.

Sayangnya, tingkat ketidakpedulian masyarakat Indonesia terhadap pengelolaan sampah tergolong tinggi, sebagaimana yang terlihat dari IPKLH (BPS, 2018: 26). Tingginya tingkat ketidakpedulian ini ditunjukkan perilaku rumah tangga di Indonesia dalam mengelola sampah. Masih banyak masyarakat yang menangani sampah tapi menimbulkan polusi dengan membakar atau membuang sampah ke sungai/selokan dan sembarang tempat. BPS mencatat pada tahun $201376.31 \%$ rumah tangga tidak memilah sampah nya. Jumlah ini meningkat di tahun 2014 menjadi $81.16 \%$.

Tabel 4. Persentase Rumah Tangga Memilah Sampah, Tahun 2013-2014

\begin{tabular}{llcc}
\hline Jenis Sampah & $\mathbf{2 0 1 3}$ & $\mathbf{2 0 1 4}$ \\
\hline $\begin{array}{l}\text { Sampah } \\
\text { dipilah }\end{array}$ & $\begin{array}{l}\text { Dipilah dan sebagian } \\
\text { dimanfaatkan }\end{array}$ & 10.28 & 8.75 \\
& Dipilah kemudian dibuang & 13.41 & 10.09 \\
& Total & 23.69 & 18.84 \\
\hline Sampah tidak dipilah & 76.31 & 81.16 \\
\hline
\end{tabular}

Sumber: BPS, 2014

Dalam penelitiannya di Kota Denpasar, Sukerti, Sudarma, dan Pujaastawa (2017) menemukan bahwa tingkat pengetahuan masyarakat merupakan faktor internal terbesar yang memengaruhi perilaku masyarakat untuk mengelola sampah. Selain itu, pendapatan, waktu luang, dan tingkat pendidikan secara berturutturut merupakan pendorong perilaku pengelolaan sampah. Di sisi lain, perilaku mengelola sampah juga dipengaruhi faktor eksternal, yaitu (1) penegakan hukum; (2) penyediaan sarana dan prasarana; dan (3) sosialisasi (Sukerti, Sudarma, \& Pujaastawa, 2017).

\section{Perilaku Memilah Sampah di Surabaya}

Pengelolaan sampah jelas tidak bisa diserahkan kepada Pemerintah saja, karena merupakan permasalahan kompleks dan berakar dari konsumsi pribadi. Oleh karena pemerintah kota Surabaya melalui Dinas Kebersihan dan Ruang Terbuka Hijau (DKRTH) memiliki misi untuk meningkatkan kualitas pengelolaan kebersihan dan pertamanan secara terpadu dengan penerapan teknologi informasi, teknologi tepat guna dan ramah lingkungan serta meningkatkan peran serta masyarakat, swasta, kerja sama regional, nasional dan internasional. Di Surabaya, pemilahan sampah dapat berbeda tergantung sumber sampah.

\section{Pemilahan Sampah di Lingkungan Tempat Tinggal}

Dalam Rencana Kerja Pemerintah Daerahnya, Pemkot Surabaya memiliki target sebesar $6,56 \%$ untuk melibatkan masyarakat dalam pengelolaan kebersihan (Jayani, 2019). Pemilahan sampah dan rumah kompos di lingkungan tempat tinggal sangat dibantu dengan adanya bank sampah dan rumah kompos. Kedua program tersebut memberikan edukasi dan akses bagi masyarakat untuk menyalurkan sampahnya.

Bank sampah di Surabaya telah terbentuk sejak 2007. Kota Surabaya memiliki bank sampah yang menjadi induk dari bank sampah lainnya, yaitu Bank Sampah Bina Mandiri yang sekarang berganti nama menjadi Bank Sampah Induk Surabaya. Mereka melayani 28 Kecamatan dari 31 Kecamatan yang ada di Kota Surabaya.

Berdasarkan hasil wawancara dengan Bank Sampah Induk Surabaya pada tanggal 15 Maret 2019 diketahui telah tumbuh 205 Unit Bank Sampah Binaan termasuk sekolah dan lembaga. Selain itu, DKRTH (2018) mencatat peningkatan jumlah bank sampah menjadi 371 di tahun 2019, dengan bank sampah ber-SK berjumlah sekitar 100 bank sampah. Bank sampah memiliki jumlah nasabah yang bervariasi, beberapa di antaranya (1) Bank Sampah Induk Surabaya yang memiliki nasabah kurang lebih 730 nasabah dengan omset mencapai Rp72 juta/bulan; (2) Bank Sampah Adiguna RW IX Babat Jerawat yang memiliki \pm 285 nasabah dengan omzet perbulan 
Rp16.540.000; (3) Bank Sampah PITOE RW III Jambangan hanya memiliki \pm 85 nasabah, namun omzetnya mencapai Rp10.500.000/bulan; (4) Bank Sampah Rukun Karya dengan nasabah \pm 168 nasabah dengan omzet Rp2.000.000/bulan; (5) Bank Sampah Jepara Makmur beromzet Rp1.600.000/bulan dengan \pm 61 nasabah; (6) Bank Sampah Makmur Sejahtera RW IV Kedung Baruk memiliki \pm 126 nasabah dan memeroleh Rp2.890.000/bulan; (7) Bank Sampah Sumber Rejeki nasabahnya \pm 102 orang dengan omzet Rp1.500.000/bulan; (8) Bank Sampah Untung Bersama RW V Morokrembangan \pm 70 nasabah dengan omzet Rp1.900.000/bulan; dan (9) Bank Sampah Bagus Karya dengan \pm 89 nasabah dan mendapatkan Rp1.000.000/bulan.

Tabel 5. Pertumbuhan Bank Sampah, Tahun 2010-2017

\begin{tabular}{cc}
\hline Tahun & Jumlah Bank Sampah \\
\hline 2010 & 15 \\
2011 & 50 \\
2012 & 135 \\
2013 & 180 \\
2014 & 200 \\
2015 & 220 \\
2016 & 260 \\
2017 & 280 \\
\hline Sumber: Profil Dinas Kebersihan dan Ruang \\
Terbuka Hijau Kota Surabaya Tahun 2018: 28
\end{tabular}

Bank Sampah Induk Surabaya (Pembina BSIS, wawancara, 15 Maret 2019) juga menyatakan kegiatan bank sampah lebih mengutamakan proses daur ulang karena ada mekanisme jual beli sampah. Dengan begitu Bank Sampah Induk mendorong masyarakat untuk memilah, mengumpulkan, dan kemudian hasilnya bisa ditabung. Petugas bank sampah memberikan layanan untuk menjemput sampah masyarakat yang sudah memenuhi kuota minimal $5 \mathrm{~kg}$. Konsep bank sampah ini mendorong masyarakat untuk melakukan metode $3 R$ (Reduce, Reuse, dan Recycle). Hasil sampah kering ditabung di bank sampah, sementara sampah basah dijadikan kompos. Pengelolaan sampah berbasis komunitas di bank sampah meliputi pemilahan sampah, penyetoran ke bank sampah, penimbangan sampah, pembayaran. Kontribusi bank sampah dalam menangani sampah komunitas ditopang oleh pembinaan terhadap masyarakat. Karena bank sampah menerima sampah rumah tangga yang sudah dipilah berdasarkan jenisnya, maka petugas tidak sekadar menerima sampah tapi juga membimbing masyarakat untuk memilah sampah.

Selain bank sampah, Pemkot Surabaya juga membina 26 Rumah kompos yang melakukan pengolahan kembali sampah organik menjadi kompos. Kompos yang dihasilkan digunakan sebagai pupuk untuk 21 taman milik Pemkot. Dengan begitu, Pemkot juga menghemat biaya pemeliharaan taman.

Tabel 6. Pertumbuhan Rumah Kompos di Surabaya, Tahun 2011-2017

\begin{tabular}{ccc}
\hline Tahun & $\begin{array}{c}\text { Jumlah Rumah } \\
\text { Kompos }\end{array}$ & Total Produksi $\left(\mathbf{m}^{3}\right)$ \\
\hline 2011 & 16 & 2717 \\
2012 & 18 & 3060 \\
2013 & 21 & 3565 \\
2014 & 25 & 4131 \\
2015 & 26 & 3939 \\
2016 & 26 & 4524 \\
2017 & 26 & 6402 \\
\hline Sumber: Profil Dinas Kebersihan dan Ruang Terbuka Hijau \\
\multicolumn{3}{c}{ Kota Surabaya Tahun 2018: 51 }
\end{tabular}

DKRTH menyediakan 400 fasilitator lingkungan untuk membantu mensosialisasikan cara-cara memilah sampah dalam upaya peningkatan kebersihan lingkungan. Fasilitator ini cukup membantu dan berperan bukan saja sebagai penyebar informasi, namun juga pengingat masyarakat sehingga motivasi memilah sampah terus terjaga.

\section{Pemilahan Sampah di Ruang Publik}

Pemilahan sampah di ruang publik dapat dilihat dari sampah yang dibuang di tempat sampah umum. Sesuai dengan acuan Peraturan Daerah Kota Surabaya Nomor 5 Tahun 2014, Pemkot Surabaya telah menyediakan fasilitas pembuangan sampah di ruang publik. 
Tabel 7. Jumlah Tempat Sampah milik DKRTH Kota Surabaya, Tahun 2018

\begin{tabular}{lc}
\hline Jenis & Jumlah \\
\hline Tempat sampah (ban karet) terbagi & 639 \\
Tempat sampah besi berstiker terbagi & 3 \\
Tempat sampah biru \& oranye terbagi & 110 \\
Tempat sampah dorong 120 lt terbagi & 161 \\
Tong Bin Beroda Uk. 100 terbagi & 100 \\
Tong Bin beroda Uk. 240 terbagi & 2 \\
\hline
\end{tabular}

Sumber: Profil Dinas Kebersihan dan Ruang Terbuka Hijau Kota Surabaya Tahun 2018: 15

Salah satu inovasi Pemkot Surabaya untuk mendorong pemilahan sampah adalah dengan program Bus Suroboyo. Program Pemkot Surabaya ini berlandaskan pada Peraturan Walikota Surabaya Nomor 67 Tahun 2018 tentang Kontribusi Sampah dalam Penggunaan Layanan Bus Surabaya. Program yang dimulai tanggal 7 April 2018 ini dikelola oleh Dinas Perhubungan, terkait armada maupun rute trayek; bekerja sama dengan dengan Dinas Kebersihan dan Ruang Terbuka Hijau (DKRTH) Kota Surabaya untuk mengumpulkan sampah plastik sebagai pengganti biaya penggunaan layanan bus. Sampah yang dimaksud di sini dikhususkan pada botol/gelas plastik yang sudah dibersihkan. Sampah ditukarkan untuk poin pelayanan dengan ketentuan satu poin bernilai: (1) tiga buah botol plastik bekas ukuran besar (kapasitas $>1.000$ $\mathrm{ml}$ ); (2) lima buah botol plastik bekas ukuran sedang (kapasitas s.d. $1.000 \mathrm{ml}$ ); atau (3) sepuluh buah gelas plastik air kemasan bekas.

Penyetoran sampah dapat dilakukan di bus Surabaya ataupun di halte bertanda khusus. Penyetoran dicatat dan dibuktikan dengan Kartu Setor Sampah yang diberikan petugas kepada calon penumpang. Setiap penumpang dapat menggunakan satu poin (stiker) untuk berkendara dengan durasi dua jam.

Menurut Ibu Nisa dari DKRTH Kota Surabaya, rata-rata Bus Suroboyo dapat mengumpulkan $200 \mathrm{~kg}$ sampah pada hari kerja, dan 400 s.d. $500 \mathrm{~kg}$ sampah plastik di akhir pekan. Sampah yang dikumpulkan berstatus Barang Milik Daerah, oleh karena itu disimpan di rumah kompos sebelum dapat dilelang. Dari bulan April s.d. Oktober 2018 DKRTH sudah berhasil melakukan sebuah pelelangan untuk 39 ton sampah plastik yang dikumpulkan sejak peluncuran program. Sampah plastik tersebut ditawarkan dengan nilai Rp80 juta dan berhasil terjual dengan harga Rp150 juta (Faqih, 2019).

Bus Suroboyo membuktikan bahwa animo masyarakat Surabaya untuk memilah sampah plastik cukup tinggi. Pembayaran dengan sampah plastik telah mengangkat nilai. Sampah plastik yang semula dianggap tidak bernilai. Persyaratan sosial ini dijelaskan Kurniawan dan Prabawati (2018) telah meningkatkan antusiasme warga Surabaya untuk menggunakan bus Surabaya. Ada 2 hal yang menjadi kunci dari kegiatan ini, yaitu: (1) Perilaku pemilahan sampah plastik dapat dibentuk dengan jika masyarakat mendapatkan keuntungan dari kegiatan tersebut; dan (2) Penyetoran sampah dilakukan di tempat yang jelas memberikan motivasi masyarakat untuk menyerahkan sampahnya.

\section{Penghambat Perilaku Memilah Sampah}

Meskipun sarana pembuangan sampah sudah disebarkan pemkot, namun masih ada saja yang membuang sampah sembarangan dan disatukan. Bahkan, masih ada yang membuang sampah di sungai, meskipun TPS terdekat hanya beberapa ratus meter dari rumahnya.

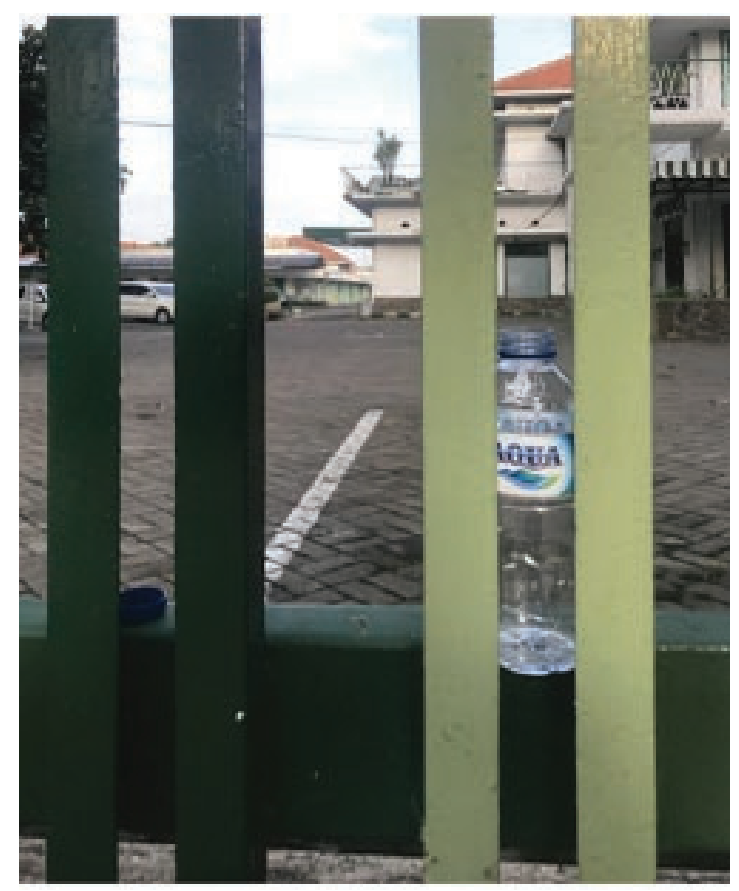

Gambar 1. Membuang sampah di pagar Rumah Sakit Darmo

Sumber: Dokumen Penelitian, 15 Maret 2019 
Pada tahun 2019, Komunitas Sea Soldier aktif mengadakan kegiatan pungut sampah di taman-taman kota Surabaya, karena masih banyak warga yang apatis terhadap penanganan sampah (Octovie, 2019). Hal ini dibenarkan oleh Pengurus Bank Sampah Induk Surabaya, yang menyatakan:

"Masih ada (pemilahan sampah), Bu, karena tidak semua sudah teredukasi. Yang sudah teredukasi pun kadang masih ada yang belum terpilah dengan betul. Setelah terpilah pun kan harus kita bersihkan." (Wawancara dengan Pembina BSIS, 25 Maret 2019)

Perilaku pemilahan sampah ini juga dapat diamati di tempat sampah. Semua sampah disatukan dalam kantong plastik untuk dibuang, baik berupa sampah basah maupun kering. Hal ini menghemat jumlah plastik yang digunakan untuk membungkus sampah. Kita terbiasa membungkus sampah dengan kantong plastik agar tidak menyebarkan bau kurang sedap.

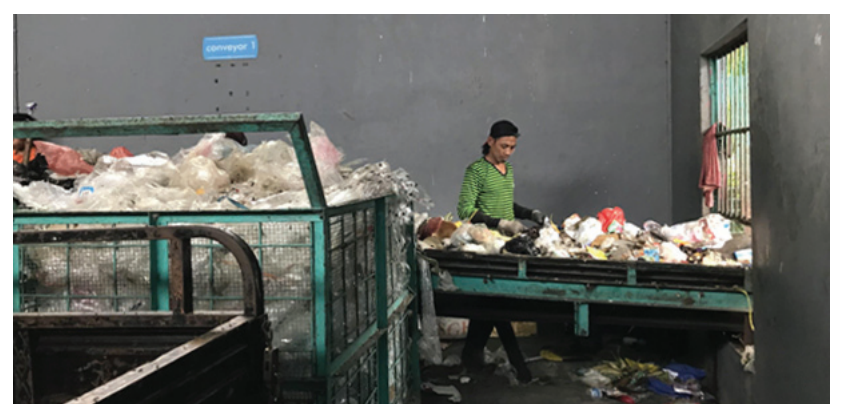

Gambar 2. Petugas Pusat Daur Ulang Jambangan Membuka Plastik Berisi Sampah Rumah Tangga Sumber: Dokumen Penelitian, 15 Maret 2019

Kebiasaan masyarakat Indonesia pada umumnya terlihat juga di Surabaya, di mana sampah yang dikumpulkan rumah tangga diangkut oleh petugas sampah untuk dibuang di TPA. Petugas sampah pun tidak meminta masyarakat untuk memilah sampahnya dan langsung memasukkan kantong sampah rumah tangga ke mobil sampah. Sampah dari perumahan ada yang diangkut dengan gerobak sampah yang terbuka. Semua sampah disatukan dalam satu gerobak untuk dibawa ke TPS/PDU (Pusat Daur Ulang). Di sinilah DKRTH menekankan fungsi fasilitator dan kader lingkungan untuk mengajak dan mengubah mindset masyarakat (Hadi, 2019; Fasilitator lingkungan, wawancara, 15 Maret
2019). Fasilitator lingkungan di Surabaya terus meningkat dari 402 orang di tahun 2011, menjadi 558 orang di tahun 2017. Sementara kader lingkungan juga ikut bertumbuh dari 27.000 kader di tahun 2011, telah bertambah menjadi 31.011 orang di tahun 2018 (DKRTH, 2018: 41).

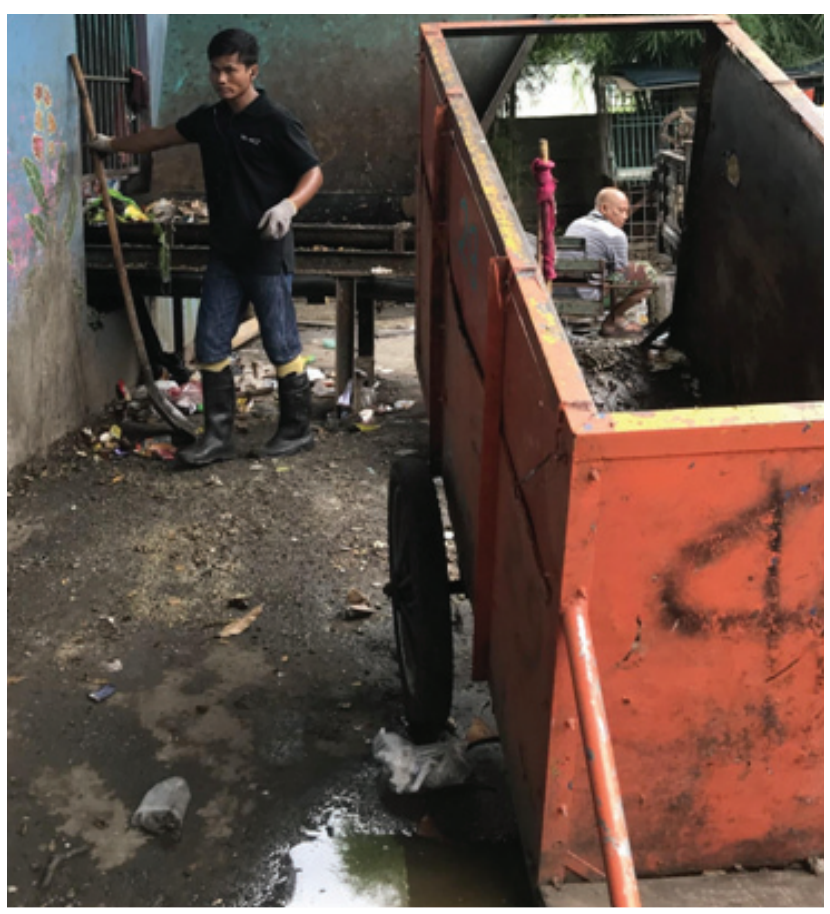

Gambar 3. Petugas dan Gerobak Sampah di Pusat Daur Ulang Jambangan

Sumber: Dokumen Penelitian, 14 Maret 2019

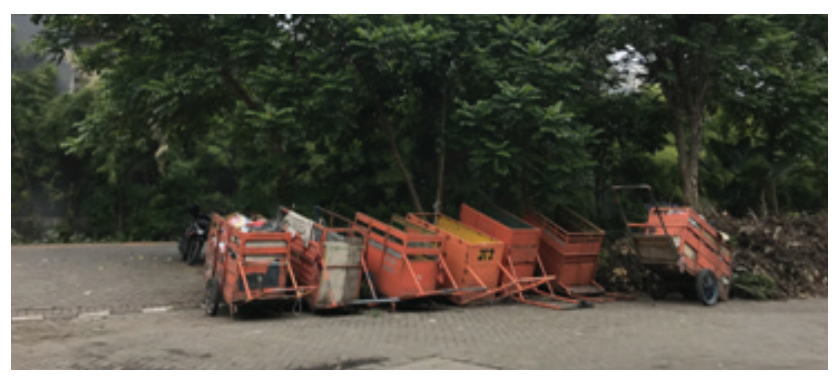

Gambar 4. Gerobak Sampah di Pusat Daur Ulang Jambangan

Sumber: Dokumen Penelitian, 14 Maret 2019

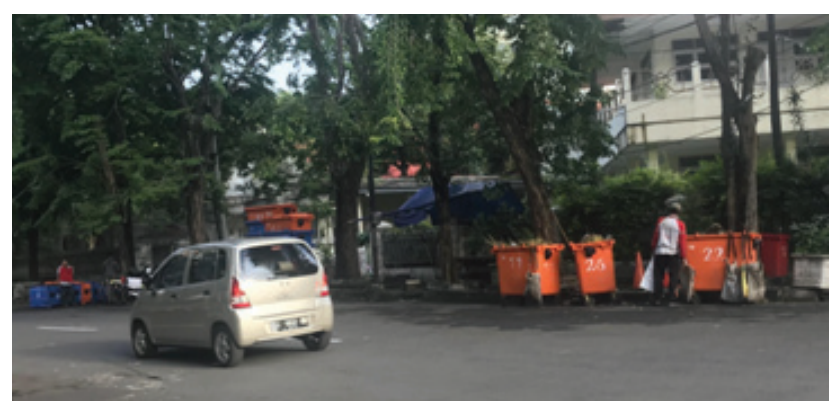

Gambar 5. Gerobak Sampah di Jalan Darmo Sumber: Dokumen Penelitian, 15 Maret 2019 
Sampah dari perumahan juga diangkut oleh mobil sampah. Mobil menurunkan sampah di TPS Ketampon, tanpa melakukan pemilahan sebagaimana terlihat pada gambar berikut. Sampah ditumpuk di bak sampah menunggu proses selanjutnya.

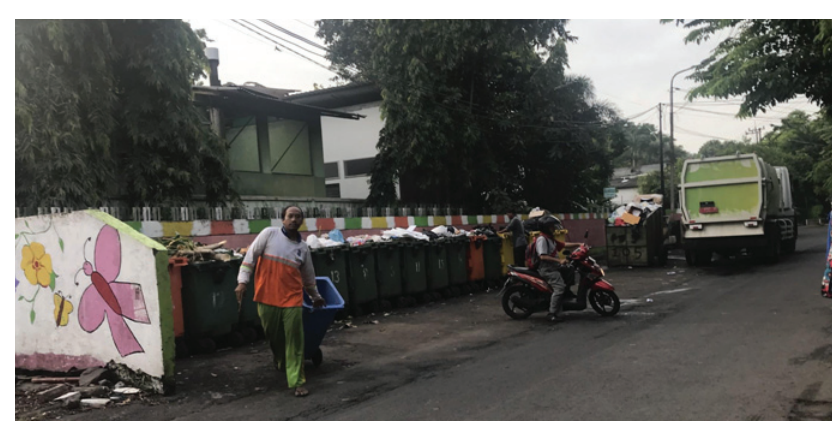

Gambar 6. TPS Ketampon dan Mobil Pengangkut Sampah

Sumber: Dokumen Penelitian, 15 Maret 2019

Meskipun ada beberapa petugas sampah yang memilah sampah di mobil sampah, hanya untuk botol dan plastik yang bernilai jual. Masyarakat yang tidak menggunakan layanan pengangkutan sampah membuang sampah di sungai. Hal ini dibuktikan oleh Komunitas Nol Sampah (Komunitas Nol Sampah, wawancara, 11 Maret 2019; Maulidiya, 2018) yang mengumpulkan sampah sepanjang 3,5 kilometer di Sungai Wonorejo.

Sesuai arahan Perwali Kota Surabaya Nomor 64/2018, Pemkot harus menyediakan sarana pemilahan sampah skala kota dalam 5 kategori. Namun, dalam observasi ditemukan tidak semua tempat sampah dibagi beberapa kelompok. Jika tempat sampah yang disediakan tidak dipisah, maka masyarakat cenderung membuang semua sampah pada tempat itu. Tempat sampah tanpa penanda membuat orang membuang semua sampah pada tempat yang sama. Tempat sampah yang terpilah memberikan informasi kepada masyarakat untuk menentukan jenis sampah yang akan dibuang. Masyarakat cenderung memasukkan sampah sesuai dengan petunjuk yang diberikan. Pembagian tempat sampah di Surabaya masih beragam, yaitu:

1) Tempat sampah biru-oranye: menyediakan tempat pembuangan untuk sampah basah (warna biru) dan sampah kering (warna oranye).
2) Tempat sampah empat jenis: untuk kertas (paper) ditandai warna ungu, plastik berwarna merah, kaleng (can) ditandai warna kuning, dan sampah organik di tempat sampah berwarna hijau botol.

3) Tempat sampah tiga jenis: organik diberi warna hijau daun, untuk plastik di tempat sampah berwarna biru, dan kertas di tempat sampah berwarna kuning.

4) Tempat sampah empat jenis yang membedakan plastik dengan warna merah, kaleng, warna oranye, kertas dengan warna biru, dan organik berwarna hijau.

5) Tempat sampah di Bus Suroboyo berwarna kuning, diperuntukkan untuk botol plastik.

Dari semua tempat sampah yang diobservasi hanya peruntukan sampah organik yang konsisten disediakan, meski tidak semuanya menggunakan warna hijau yang sama. Sementara itu, tempat pembuangan di TPS tidak dibedakan berdasarkan jenis sampahnya.

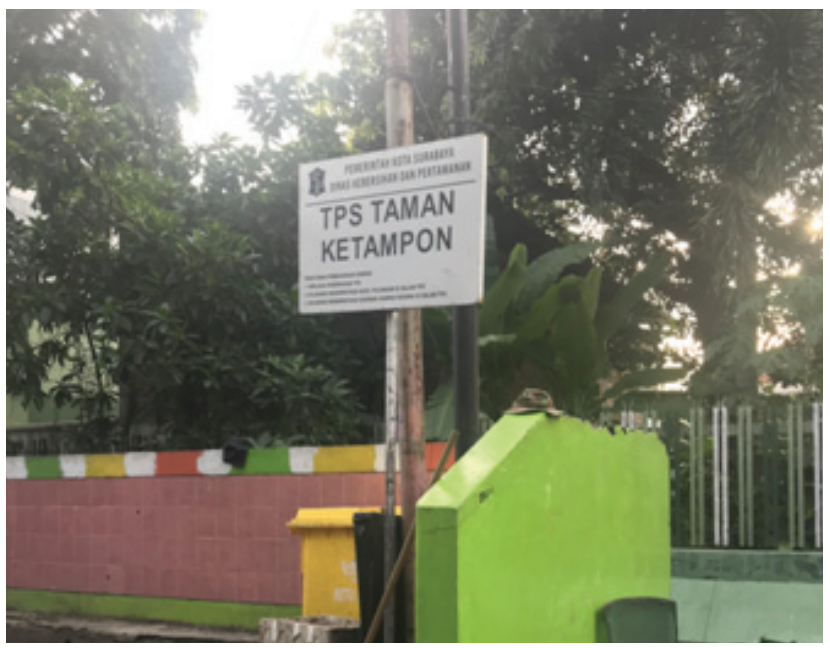

Gambar 7. TPS Taman Ketampon

Sumber: Dokumen Penelitian, 15 Maret 2019

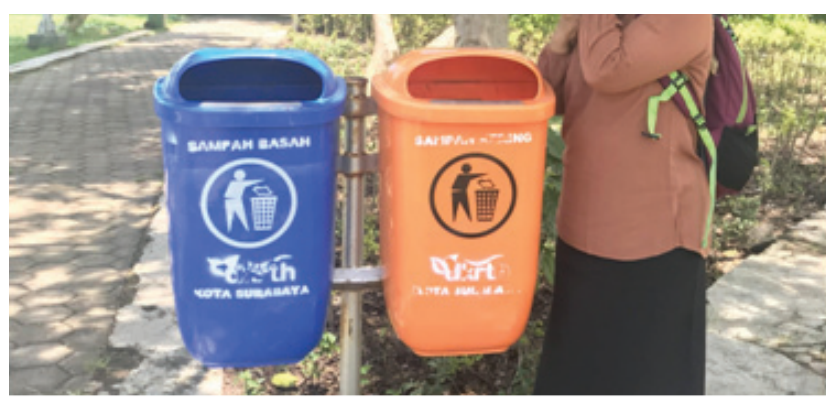

Gambar 8. Tempat Sampah di Taman Harmoni, Surabaya

Sumber: Dokumen Penelitian, 13 Maret 2019 


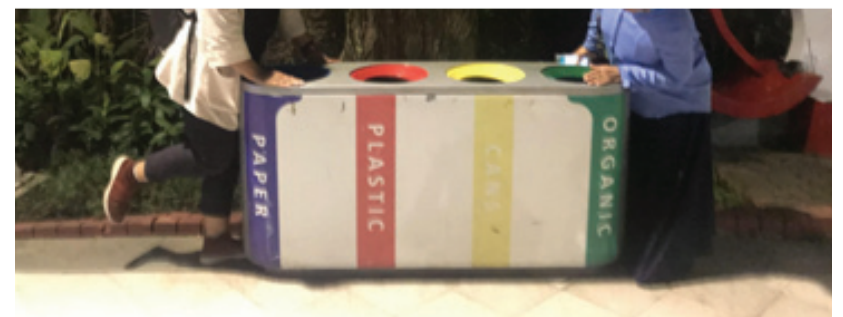

Gambar 9. Tempat Sampah di Taman Bungkul, Surabaya

Sumber: Dokumen Penelitian, 11 Maret 2019

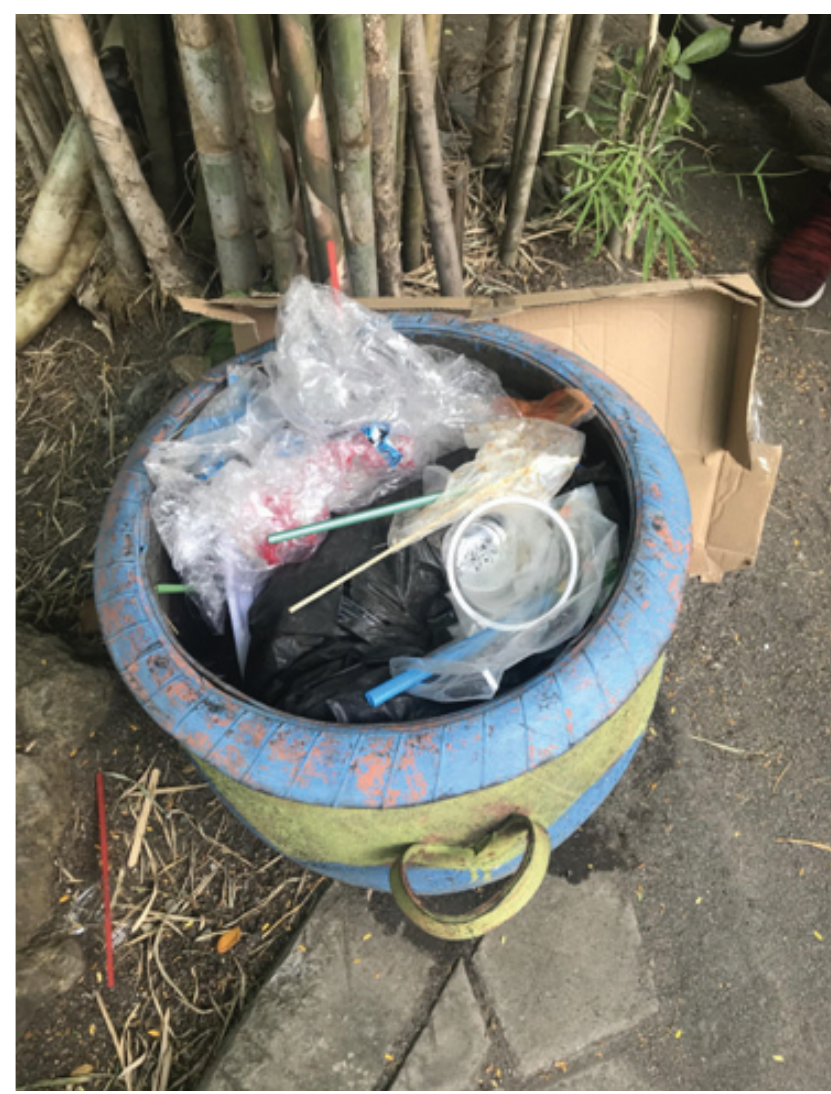

Gambar 10. Tempat Sampah di Taman Harmoni Sumber: Dokumen Penelitian, 13 Maret 2019

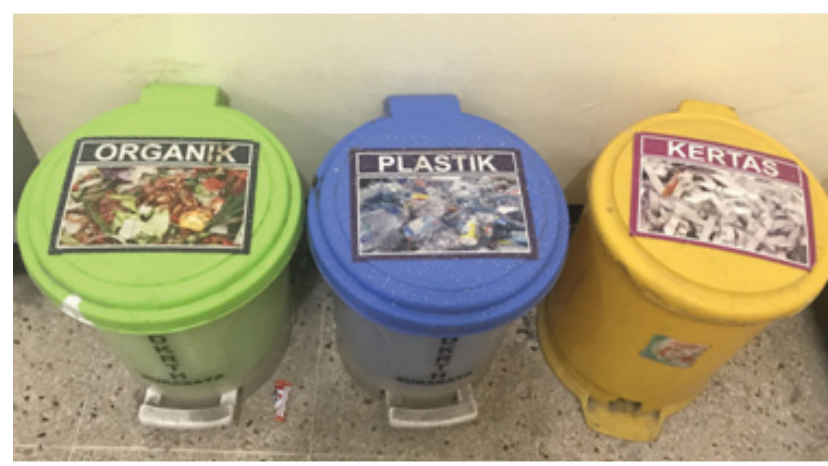

Gambar 11. Tempat Sampah di DKRTH Kota Surabaya

Sumber: Dokumen Penelitian, 11 Maret 2019

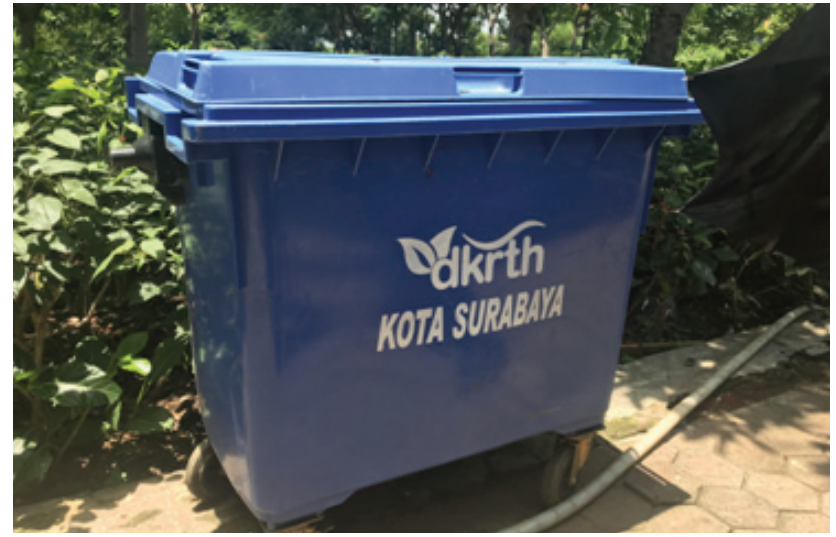

Gambar 12. Tempat Sampah di Taman Harmoni Sumber: Dokumen Penelitian, 13 Maret 2019

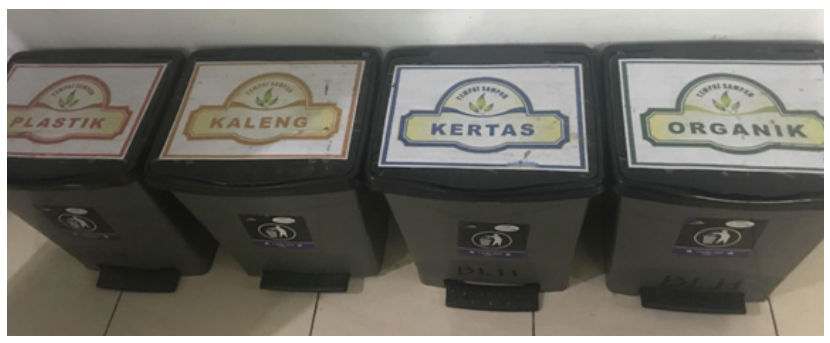

Gambar 13. Tempat Sampah di Kantor Pemerintah Kota Surabaya

Sumber: Dokumen Penelitian, 13 Maret 2019

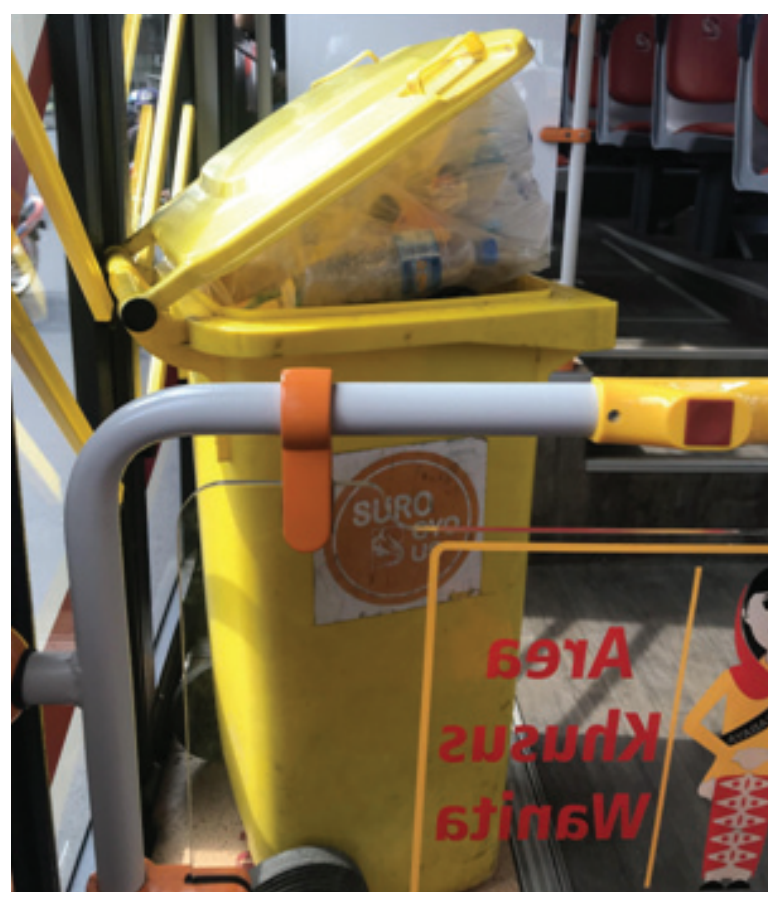

Gambar 14. Tempat Sampah di Bus Suroboyo Sumber: Dokumen Penelitian, 15 Maret 2019

Dari wawancara dan observasi di atas, penulis menyimpulkan ada beberapa hambatan yang membuat pemilahan sampah menjadi sulit. Pertama, kurangnya pengetahuan masyarakat 
mengenai klasifikasi sampah dan bagaimana penanganannya. Kedua, sarana tidak mendukung. Ketiga, pengaruh sosial. Orang cenderung memasukkan sampah sesuai peruntukannya jika berada di tempat yang semua orang memilah sampah. Bisa dilihat dari tempat sampah yang rapi di Taman Bungkul dan Taman Harmoni. Akan tetapi, ketika di tempat orang tidak memilah sampah, sampah dimasukkan seenaknya.

\section{Strategi Pembentukan Perilaku Pemilahan Sampah}

Tiga hal yang menjadi hambatan pemilahan sampah perlu ditangani. Selama ini kita terbiasa membuang sampah seenaknya. Penulis sependapat dengan Mezghenni dan Zouari (2016: 7) yang menyatakan refleks membuang dan ketidaktahuan merupakan dua dari beberapa penyebab orang membuang sampah sembarangan. Membuang sampah di sungai dilakukan agar sampah menghilang dari lingkungan pembuang. Namun, pembuang tidak mempertimbangkan bahwa sampah ini akan: (1) tersangkut di sungai yang kering sehingga meracuni air sungai; (2) menghambat aliran sungai yang dapat menimbulkan banjir; atau (3) hanyut sampai ke laut yang akan membahayakan ekosistem laut.

Ketidaktahuan masyarakat ini merupakan tantangan bagi pemerintah, yang menunjukkan masih rendahnya transfer informasi. Pengetahuan masyarakat dibentuk oleh berbagai hal, mulai dari sosialisasi dari petugas/sumber daya manusia yang terkait dengan pengelolaan sampah (baik itu petugas sampah, bank sampah, maupun fasilitator lingkungan), arahan dari pemimpin dan masyarakat setempat (ketua RT dan tetangga), hingga informasi yang didapat dari sarana kebersihan di lingkungannya. Sebagai parameter perilaku pemilahan sampah, Pemkot Surabaya memiliki Peraturan Walikota Nomor 10 Tahun 2017 tentang Tata Cara Pengenaan Sanksi Administratif Pelanggaran Peraturan Daerah Kota Surabaya Nomor 5 Tahun 2014 tentang Pengelolaan Sampah dan Kebersihan di Kota Surabaya. Pada Perda Kota Surabaya No 5/2014 telah dirinci beberapa larangan untuk mengurangi sampah, yaitu: (1) membuang sampah tidak pada tempat yang telah ditentukan dan disediakan, termasuk membuang sampah ke sungai, selokan, got, riol, saluran, jalan umum, tempat umum, berm atau trotoar dan/atau di tempat umum lainnya; (2) membuang sampah ukuran besar di TPS/TPST dan/atau TPA, saluran; (3) membuang sampah puing bongkaran bangunan ke TPS/ TPST dan/atau TPA; (4) memasukkan sampah dari luar wilayah daerah ke TPS/TPST dan/atau TPA kecuali mendapat izin dari walikota; (5) menumpuk sampah di luar kontainer dan/atau gerobak di kawasan TPS/TPST; (6) menumpuk sampah di luar landfill di kawasan di TPA; (7) membuang sampah yang mengandung bahan berbahaya dan beracun (B3) ke TPS/TPST dan/atau TPA; (8) mencampur sampah dengan bahan berbahaya dan beracun; (9) membakar sampah yang tidak sesuai dengan persyaratan teknis pengelolaan sampah; (10) mengelola sampah yang menyebabkan pencemaran dan/atau perusakan lingkungan.

Pelanggaran terhadap larangan $\mathrm{di}$ atas akan diganjar dengan sanksi administratif secara bertingkat. Pertama, dengan teguran. Kedua, diberikan peringatan tertulis. Ketiga, tindakan pemaksaan oleh pemerintah, antara lain pengambilan KTP, penghentian sementara kegiatan, pembongkaran, penyitaan barang yang berpotensi menimbulkan pelanggaran, penghentian sementara seluruh kegiatan, atau tindakan lain yang dapat menghentikan pelanggaran dan memulihkan fungsi lingkungan hidup. Jika pelanggaran menyebabkan ancaman serius bagi manusia dan lingkungan, berpotensi menimbulkan dampak dan kerugian lingkungan yang lebih besar, maka paksaan dapat dilakukan tanpa harus didahului teguran dan/atau peringatan tertulis. Keempat, ditagih uang paksa yang diterapkan jika pelanggar terlambat menghentikan pelanggaran atau tidak sanggup memulihkan kondisi sesuai ketentuan yang berlaku. Besaran uang paksa per hari dapat dilihat di Tabel 8 . Jumlahnya cukup variatif dari Rp75.000 sampai Rp1.500.000. Terakhir, kelima, pemerintah dapat melakukan pencabutan izin; bahkan sampai pada tahap terakhir, yaitu penutupan usaha/kegiatan.

Penegakkan hukum yang sudah dilakukan oleh DKRTH Kota Surabaya, yaitu sampai penyitaan KTP, yang akan diblokir jika dalam dua hari KTP yang disita tidak diambil. Akan tetapi, diakui bahwa tindakan represif ini belum 
Tabel 8. Contoh Besaran Uang Paksa per Hari

\begin{tabular}{lcc}
\hline \multicolumn{1}{c}{ Jenis Pelanggaran } & $\begin{array}{c}\text { Volume } \\
\text { Sampah }\end{array}$ & $\begin{array}{c}\text { Besaran Uang } \\
\text { Paksa (Rupiah) }\end{array}$ \\
\hline Membuang sampah tidak pada tempat yang telah ditentukan dan disediakan, & $\leq 0,5 \mathrm{~m}^{3}$ & 75.000 \\
termasuk membuang sampah ke sungai, selokan, got, riol, saluran, jalan & $0,51-1 \mathrm{~m}^{3}$ & 150.000 \\
umum, tempat umum, berm atau trotoar dan/atau di tempat umum lainnya. & $>1 \mathrm{~m}^{3}$ & 750.000 \\
\hline Membuang sampah ukuran besar di TPS/TPST dan/atau TPA, saluran & $>1 \mathrm{~m}^{3}$ & 750.000 \\
\hline Membuang sampah puing bongkaran bangunan ke TPS/TPST dan/atau TPA & $\leq 1 \mathrm{~m}^{3}$ & 300.000 \\
& $>1 \mathrm{~m}^{3}$ & 1.500 .000 \\
\hline Sampah dari luar wilayah daerah ke TPS/TPST dan/atau TPA kecuali & $0-1 \mathrm{~m}^{3}$ & 150.000 \\
mendapat izin dari walikota & $>1 \mathrm{~m}^{3}$ & 750.000 \\
\hline Menumpuk sampah di luar kontainer di kawasan TPS/TPST & $\leq 0,5 \mathrm{~m}^{3}$ & 75.000 \\
& $0,51-1 \mathrm{~m}^{3}$ & 150.000 \\
\hline Menumpuk gerobak di kawasan TPS/TPST & $>1 \mathrm{~m}^{3}$ & 750.000 \\
\hline Menumpuk sampah di luar landfill di kawasan di TPA & 150.000 \\
\hline Membakar sampah yang tidak sesuai dengan persyaratan teknis pengelolaan & 750.000 \\
\hline sampah & & 300.000 \\
\hline Mengelola sampah yang menyebabkan pencemaran dan/atau perusakan & 280 & 300.000 \\
\hline
\end{tabular}

Sumber: Perwali Kota Surabaya 10/2017

efektif untuk mencegah sampah. Oleh karena itu, Pemkot Surabaya beserta LSM terkait terus menjalankan berbagai program sosialisasi yang menyasar kelompok-kelompok kecil masyarakat, seperti lingkungan RT dengan fasilitator dan kader lingkungan, bank sampah, maupun ke sekolah dengan program eco-school atau sekolah adiwiyata. Dalam sosialisasi, masyarakat dibekali cara untuk memilah sampah.

Sarana kebersihan juga memiliki peran penting untuk membentuk perilaku pemilahan sampah. Masyarakat mengetahui klasifikasi sampah dari tempat sampah yang disediakan di ruang publik. Meskipun begitu, tidak jarang kita melihat sampah ditumpuk dalam sebuah keranjang sampah begitu saja. Hal ini dilakukan untuk menghemat waktu (Mezghenni \& Zouari, 2016: 7). Oleh karena itu, tempat sampah khusus sangat membantu mengarahkan perilaku membuang sampah pada tempat yang tepat.

Tempat sampah khusus adalah tempat sampah yang membedakan jenis sampah yang harus dibuang. Meskipun telah ada pengklasifikasian sampah, namun tidak semua tempat sampah di Surabaya diberi tanda sesuai klasifikasi yang sudah diatur. Ada yang hanya membedakan sampah organik dengan anorganik, sedangkan ada yang membedakan sampah kertas, plastik, dan organik, ada juga yang menyediakan tempat khusus untuk kaleng. Kondisi ini tidak hanya terjadi di Surabaya. Menurut penelitian Andrews, Gregoire, Rasmussen, dan Witowich (2013) dalam suatu yurisdiksi atau institusi di Amerika terdapat simbol sampah dan tempat sampah yang berbeda. Tidak seperti rambu lalu lintas, penanda tempat pembuangan sampah sering kali tidak seragam.

Orang cenderung berperilaku seperti yang diperlihatkan kebanyakan orang. Di Indonesia yang menurut Hofstede (2011: 11) memiliki budaya kolektivisme. Dalam budaya ini orang ingin menyesuaikan perilakunya dengan mayoritas agar ia merasa menjadi bagian dari kelompok mayoritas tersebut. Komunitas komunal menjadikan perilaku kebanyakan orang sebagai barometer perilakunya. Meminjam Theory of Planned Behavior (TPB), Xu, Ling, Lu, dan Shen (2017: 3) mengingatkan bahwa ketika orang tidak yakin apa yang seharusnya dilakukan mereka mengambil kesimpulan dari observasi perilaku orang lain. Ini yang disebut dengan tekanan sosial dalam teori tersebut. TPB 
menekankan bahwa niat dan perilaku seseorang dibentuk dari sikap, norma subjektif dan kontrol terhadap perilaku yang dipersepsikan (Xu et al., 2017). Perilaku memilah sampah juga dapat dijelaskan dengan teori ini. Orang membuang sampah pada tempat yang sudah disediakan karena melihat orang lain melakukan hal yang sama. Misalnya orang cenderung membuang sampah plastik ke tempat sampah yang ditandai untuk sampah plastik, ketika melihat isi tempat sampah memang hanya berisi plastik. Sebaliknya, jika tempat sampah tidak dipisah dan orang melihat berbagai sampah dimasukkan ke tempat itu, maka ia tidak ragu untuk melakukan hal yang sama.

Bank sampah memiliki efek positif untuk mendorong gerakan komunal memilah sampah. Petugas Bank Sampah senantiasa memberikan edukasi dan dukungan untuk memilah sampah, seperti yang ditemukan Fransiska Tanuwijaya pada penelitiannya di Bank Sampah PITOE Jambangan di tahun 2016. Selain itu, bank sampah juga mendorong masyarakat untuk bersosialisasi dan menjaga kebersihan. Dukungan pemimpin yang menjadi teladan juga mendorong masyarakat ikut serta dalam kegiatan pengelolaan sampah di lingkungannya (Tanuwijaya, 2016).

Oleh karena itu, peneliti merumuskan 3 hal yang penting untuk membentuk perilaku memilah sampah, yaitu kebijakan, sarana, dan peran serta masyarakat dalam membagi pengetahuan. Konsep ini sejalan dengan hasil penelitian Sukerti, Sudarma, dan Pujaastawa (2017) di Denpasar. Ketiga aspek tersebut mereka kategorikan sebagai faktor eksternal yang memengaruhi perilaku masyarakat dalam membuang sampah.

Fokus pada 3 hal tersebut dapat membentuk perilaku dan budaya memilah sampah, sebagaimana pendekatan yang dilakukan Molstad et al. (2018) untuk membentuk perilaku pemilahan sampah sekolah di Thailand, yaitu dengan 3 strategi sebagaimana dijelaskan dalam Gambar 15.

\section{Penguatan Kebijakan}

Pada tahun 2010, China mulai menetapkan peraturan pemilahan sampah yang ketat (China Daily, 2010). Mereka yang membuang sampah

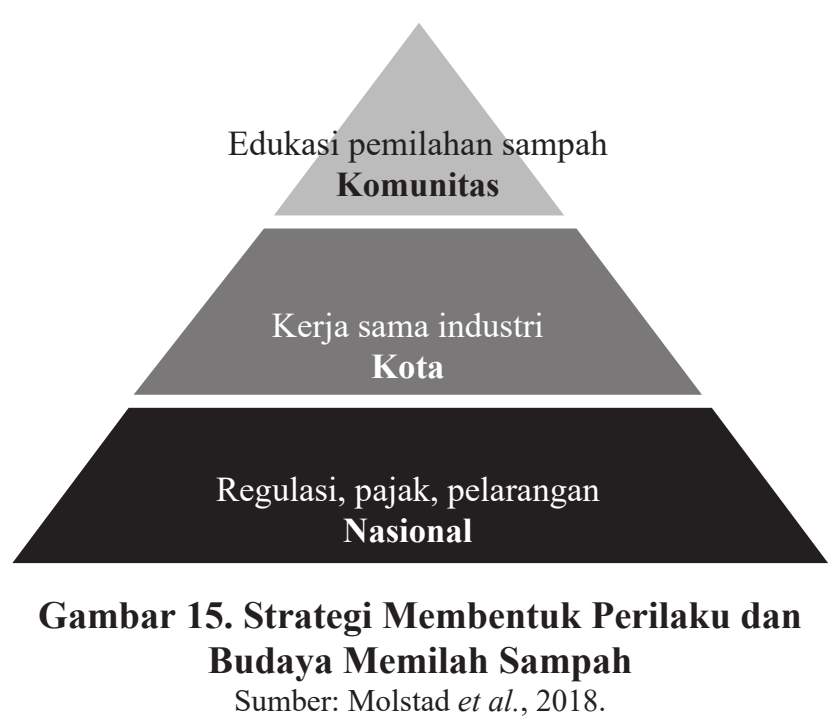

sembarangan diberi denda 20 hingga 200 Yuan, dan denda 5.000 sampai 50.000 Yuan bagi korporasi yang membuang sampah seenaknya. Sebaliknya mereka yang mengurangi timbulan sampah akan mendapatkan penghargaan. Mulai tahun 2019, Kota Shanghai melakukan propaganda aktif dengan slogan "Sampah tipe apa kamu?" yang memaksa penduduk untuk mengelompokkan sampahnya dalam 4 kategori: kering, basah, didaur ulang, dan berbahaya (Kuo, 2019). Bukan saja poster, pemerintah kota juga menyediakan aplikasi dan volunter untuk memberikan informasi dan supervisi kepada masyarakat agar dapat mengidentifikasikan sampahnya.

Konsep reward and punishment ini sebenarnya sudah tertuang dalam kebijakan penanganan sampah kita. Dalam Pasal 29 UU Pengelolaan Sampah dinyatakan Setiap orang dilarang: (1) memasukkan sampah ke dalam wilayah Negara Kesatuan Republik Indonesia; (2) mengimpor sampah; (3) mencampur sampah dengan limbah berbahaya dan beracun; (4) mengelola sampah yang menyebabkan pencemaran dan/atau perusakan lingkungan; (5) membuang sampah tidak pada tempat yang telah ditentukan dan disediakan; (6) melakukan penanganan sampah dengan pembuangan terbuka di tempat pemrosesan akhir; dan/atau (7) membakar sampah yang tidak sesuai dengan persyaratan teknis pengelolaan sampah.

Untuk menjaga kepatuhan atas larangan di atas pemerintah daerah diberi kebebasan menetapkan sanksi pidana atau denda. Di 
DKI Jakarta, pembuang sampah sembarangan diancam denda Rp500.000 dengan Perda Nomor 3 Tahun 2013 tentang Pengelolaan Sampah ataupun pidana 10 hari sampai 2 bulan atau denda Rp100.000 sampai Rp20 juta sebagaimana diatur dalam Perda Nomor 8 Tahun 2007. Di Surabaya denda/uang paksa ditetapkan serendah-rendahnya Rp75.000 dan setinggi-tingginya Rp1.500.000. Akan tetapi, pada praktiknya kebijakan ini sulit diimplementasikan. Belum pernah ada orang yang dipidana atau didenda karena membuang sampah sembarangan. Pemkot Surabaya baru dapat menyita KTP dan memblokir KK warga yang membuang sampah sembarangan

Petugas kebersihan yang ada dianggap sebagai pembantu yang akan menyelesaikan kekotoran yang dibuat masyarakat. Tidak salah jika pola pikir yang berkembang adalah tidak perlu membersihkan sampah sendiri karena sudah ada yang dibayar untuk melakukan pembersihan. Padahal, kebijakan tidak hanya berfungsi sebagai sumber informasi, yaitu memberikan pengetahuan mengenai pemilahan sampah kepada masyarakat. Kebijakan perlu disosialisasikan di area publik dan instansi pendidikan baik secara konvensional maupun menggunakan teknologi digital. Kampanye media sosial terbukti menjadi cara yang efektif untuk menyuplai informasi kepada masyarakat.

Burn (1991: 612) menyatakan usaha legislasi untuk membuat kebijakan yang kadang menuntut kewajiban masyarakat dapat membantu meningkatkan kepatuhan masyarakat jika didukung kemudahan untuk melaksanakan kewajiban tersebut. Misalnya kebijakan untuk mendaur ulang telah mendorong peningkatan kegiatan daur ulang ketika (1) adanya layanan penjemputan ke rumah; dan (2) pesan yang jelas kepada masyarakat mengenai pentingnya kegiatan ini. Oleh karena itu, jika pemerintah belum dapat mengimplementasikan aturan secara konsisten, maka akan sulit untuk membentuk perilaku pemilahan sampah.

Kebijakan ini tidak hanya berlaku pada masyarakat, tapi juga terhadap pemerintah. Kebijakan semestinya memaksa Pemkot untuk melayani dan mendorong masyarakat untuk berpartisipasi, sehingga terjadi kolaborasi yang dapat meningkatkan efektivitas pemilahan sampah. Yang sering terjadi adanya pembiaran ketika pemerintah tidak dapat memenuhi standar pelayanan dasarnya. Untuk itu, Pemkot harus berani mengakui dan mengevaluasi kinerjanya. Pemkot Surabaya belum mampu memenuhi tuntutan penyediaan tempat sampah terpilah, sehingga perlu dilakukan perubahan strategi agar target-targetnya dapat dicapai.

\section{Penyediaan Sarana yang Ergonomis}

Kunci perubahan perilaku menurut Molstad et al. (2018) adalah memberikan kemudahan bagi untuk melakukan penyortiran sampah. Caranya adalah memastikan sarana penyortiran sampah dekat, jelas, tepat, dan memadai. Di Surabaya tempat sampah disebar ke seluruh fasilitas umum dengan jarak berdekatan.

Namun begitu, ketidakseragaman penandaan tempat sampah dapat menyebabkan kebingungan dan kekesalan masyarakat, yang berujung pada pemilahan yang tidak tepat (Wu, Lenkic, DiGiacomo, Cech \& Zhao, 2018: 77). Prinsip ergonomi dalam penandaan tempat sampah sangat diperlukan karena dengan penamaan yang tepat akan mampu menyampaikan pesan yang komprehensif kepada masyarakat. Sebuah rambu yang dapat menyebabkan perubahan perilaku spesifik haruslah (1) menarik perhatian; (2) membantu pemahaman; (3) memodifikasi keyakinan dan sikap; kemudian (4) meningkatkan motivasi (Wogalter \& Laughery, dalam Wu et al., 2018: 78).

$\mathrm{Wu}$ et al. (2018: 83) menyarankan kesederhanaan petunjuk di tempat pembuangan sampah untuk menghindari kelebihan informasi dan gangguan kinerja. Oleh karena itu, yang perlu ditampilkan hanyalah bentuk sampah yang umum. Penggunaan gambar sebenarnya lebih efektif (Wu et al., 2018: 83), namun akan menjadi penghalang jika gambar tidak bagus atau sesuai dengan bentuk sampah aslinya. Penulisan kata yang menggunakan huruf besar, terang, dan tidak banyak hiasan (Wu et al., 2018: 83) akan ergonomis untuk menandai pengklasifikasian sampah.

Penyeragaman ini merupakan sebuah bentuk pendidikan untuk menyamakan pola pikir masyarakat. Hal ini disebutkan Profesor Psikologi Jessica Nolan yang menjelaskan bahwa 
bahan pendidikan yang seragam di seluruh komunitas dapat menghilangkan kebingungan, agar masyarakat dapat membedakan jenis sampah (yang dapat didaur ulang) (Schumacher, 2016). Keseragaman pembagian tempat sampah juga berperan sebagai penguat (reinforcement) perilaku memilah sampah. Pembedaan tempat sampah dimaksudkan untuk membentuk kesan kuat bahwa sampah harus dipisahkan. Jika orang terus menerus dihadapkan dengan kondisi pembagian tempat sampah yang sama, maka akan tercipta ingatan pengklasifikasian sampah. Dengan begitu, ia dapat mengasosiasikan tempat sampah yang benar.

\section{Pelibatan Masyarakat dalam Mengubah Perilaku}

Pengelolaan sampah tidak bisa diserahkan sepenuhnya kepada pemerintah. Oleh karena itu, pemerintah perlu mendorong partisipasi masyarakat untuk ikut berpartisipasi dalam penanganan sampah. Pengaturan sampah yang tidak melibatkan masyarakat menumbuhkan ketidakpedulian akan upaya pengelolaan sampah. Hakim (2014: 39) menekankan pentingnya peran serta masyarakat karena penanganan sampah terbaik dimulai dari sumber. Semakin dekat dengan sumbernya maka semakin besar rasa memiliki (sense of belonging) dan rasa tanggung jawab orang untuk mengelola sampahnya. Menurut Hakim (2014: 40) perlu ada upaya merubah kebiasaan, sikap dan perilaku masyarakat dengan menumbuhkan dan mengembangkan peran serta masyarakat dalam bidang kebersihan. Masih rendahnya keterlibatan masyarakat disebabkan kurangnya pembinaan dari pemerintah. Peran ini dapat diwujudkan dengan cara: (1) memberikan usul, pertimbangan, dan saran kepada pemerintah/pemerintah daerah; (2) memberikan usulan dalam perumusan kebijakan pengelolaan sampah; (3) pemberian saran dan pendapat dalam penyelesaian sengketa persampahan.

Upaya propaganda untuk membentuk kesan perlunya pemilahan sampah. Pemkot Surabaya menjawab tantangan ini dengan berbagai program edukasi ke sekolah dan perguruan tinggi, yaitu dengan eco-school, sekolah adiwiyata, ecocampus, dan eco-pesantren. Di tingkat lingkungan
RT, edukasi diserahkan kepada komunitas masing-masing. Akan sangat membantu jika ada bank sampah terdekat yang dapat memberikan sosialisasi mengenai pemilahan sampah. Namun, tidak semua RT memiliki bank sampah.

Molstad et al. (2018: iii) mengingatkan bahwa perubahan perilaku individu merupakan hal yang sulit dan tidak efisien. Akan lebih bermanfaat jika kita dapat mengubah sistem, ketimbang hanya berfokus pada individu. Edukasi adalah strategi yang menyediakan informasi mengenai penggunaan dan dampak plastik untuk mengubah perspektif dan perilaku (Molstad et al., 2018: 5). Meskipun edukasi telah memberikan informasi, namun belum tentu mengubah perilaku orang dalam menggunakan plastik. Di Thailand dan Kamboja, pendekatan edukasi untuk meningkatkan kesadaran memang mengundang partisipasi aktif dari audiensnya, namun hanya sedikit yang dapat dirangkul dari program-program tersebut (Molstad et al., 2018: 6). Logikanya orang yang tidak membuang sampah pada tempatnya adalah mereka yang tidak diajarkan norma sosial (Kort, McCalley, \& Midden, 2008: 2). Sayangnya program pendidikan masih belum dapat dievaluasi kaitannya dengan perilaku membuang (Kort, McCalley, \& Midden, 2008: 2) apalagi memilah sampah.

Oleh karena itu, Molstad et al. (2018) menyarankan strategi 3 tahapan dengan jumlah audiens yang semakin besar. Program edukasi penting untuk membentuk kesadaran dan dukungan atas program pemilahan sampah, namun perubahan tata ruang yang didukung oleh industri dan kebijakan nasional perlu diperhatikan sebagai pemicu munculnya perilaku pemilahan. Penulis melihat bahwa program sosialisasi dan pendidikan sudah banyak dijalankan di Kota Surabaya. Namun, pemilahan sampah bukan hanya masalah pengetahuan, tapi lebih dipengaruhi situasi dan kebiasaan. Ada orang yang mengetahui pentingnya memilah sampah, namun tidak melakukan karena orang lain tidak berperilaku serupa. Oleh karena itu, penekanan pada tekanan sosial menjadi penting di mana seseorang perlu berada di lingkungan yang melakukan pemilahan sampah. Dengan begitu, ia pun akan ikut melakukan hal yang sama. 
Untungnya di Surabaya telah terjadi pergerakan gerilya untuk mengajarkan pemilahan sampah di komunitas terkecil melalui fasilitator lingkungan. Selain mengajarkan cara menangani sampah, mereka juga bertugas mengingatkan masyarakat untuk memilah sampah. Pengingat ini lama-lama akan menumbuhkan kebiasaan masyarakat. Para fasilitator menekankan bahwa sampah merupakan tanggung jawab masingmasing individu, sehingga setiap orang harus mampu mengelola sampahnya sendiri.

Kebijakan, sarana, dan pelibatan masyarakat merupakan faktor eksternal yang secara situasional menempatkan individu pada kondisi memilah sampah. Faktor eksternal lebih mudah dimodifikasi untuk mendapatkan perlakuan tertentu.

\section{Penutup}

Surabaya dikenal dengan program pengelolaan sampah yang diakui dunia. Akan tetapi, belum memastikan setiap warganya mendukung program kebersihan, salah satunya dengan melakukan pemilahan sampah. Masih banyak masyarakat yang tidak memilah sampah, meskipun berbagai sosialisasi gencar diberikan Pemkot.

Untuk membuat orang mau memilah sampah tidak hanya bergantung pada nilai pribadi (faktor internal), tapi perlu disiapkan suasana yang mendukung. Penulis menemukan adanya 3 strategi eksternal untuk mendorong perilaku pemilahan sampah: (1) penguatan kebijakan, di mana pengaturan harus diimplementasikan secara maksimal dan konsisten; (2) penyediaan sarana yang ergonomis, yaitu yang tepat penempatannya, sesuai peruntukannya, dan konsisten penandaannya;(3)pelibatan masyarakat dalam mengubah perilaku, dengan memanfaatkan sifat komunal masyarakat Indonesia maka perlu dibuat kebiasaan bersama sehingga setiap orang saling dikuatkan oleh perilaku pemilahan sampah orang lain di komunitasnya.

\section{Keterbatasan Penelitian}

Penelitian ini hanya memfokuskan pada faktor eksternal yang memengaruhi perilaku memilah sampah, sehingga tidak dapat menghubungkan dengan faktor internal yang memengaruhi perilaku tersebut. Untuk itu, jika ada peneliti yang berminat melanjutkan penelitian ini dapat mengulas mengenai faktor internal yang memengaruhi perilaku pemilahan sampah.

\section{Ucapan Terima Kasih}

Penulis mengucapkan terima kasih kepada pihak-pihak yang telah membantu pembuatan paper ini, antara lain: (1) Tim Penelitian Kebijakan Pembatasan Sampah Plastik Sekali Pakai dan Implikasinya terhadap Industri dan Masyarakat (Studi di Kota Bandung dan Kota Surabaya): Sri Nurhayati Qodriyatun, Ujianto Singgih Prayitno, Yulia Indahri, Anih Sri Suryani, dan Teddy Prasetiawan; (2) Para narasumber: Kementerian Kehutanan dan Lingkungan Hidup, Dinas Kebersihan dan Ruang Terbuka Hijau Kota Surabaya, Dinas Lingkungan Hidup Kota Surabaya, Pengelola Taman Harmoni, Bank Sampah Induk Surabaya, Fasilitator Lingkungan Hidup di kecamatan, dan Komunitas Nol Sampah.

\section{Daftar Pustaka}

Andrews, A., Gregoire, M., Rasmussen, H., \& Witowich, G. (2013). Comparison of recycling outcomes in three types of recycling collection units. Waste Management, 33(3), 530-535. doi: 10.1016/J.WASMAN.2012.08.018

Anifa, T., Anward, H. H., \& Erlyani, N. (2017). Perbedaan Perilaku Membuang Sampah Pada Siswa Antara Sebelum Dan Sesudah Diberikan Live And Symbolic Modeling. Jurnal Ecopsy, 4(2), 96-102.

Blouin, L. (2016, January 8). The Psychology of Littering - The Allegheny Front. Retrieved from https://www.alleghenyfront.org/thepsychology-of-littering/, on 26 November 2019.

BPS. (2018). Laporan Indeks Ketidakpedulian terhadap Lingkungan Hidup. Jakarta: Badan Pusat Statistik Republik Indonesia.

BPS. (2019, April 15). Indeks Pembangunan Manusia (IPM) Jawa Timur Tahun 2018. Retrieved from https://jatim.bps.go.id/ pressrelease/2019/04/15/1068/indekspembangunan-manusia--ipm--jawa-timurtahun-2018.html, on 11 September 2019. 
BPS. (2014). Persentase Rumah Tangga Menurut Provinsi dan Perlakuan Memilah Sampah Mudah Membusuk dan Tidak Mudah Membusuk, 2013-2014. Retrieved from https://www.bps. go.id/statictable/2014/05/02/1360/persentaserumah-tangga-menurut-provinsi-dan-perlakuanmemilah-sampah-mudah-membusuk-dan-tidakmudah-membusuk-2013-2014, on 4 September 2019.

Bohm, R. A., Folz, D. H., Kinnaman, T. C., \& Podolsky, M. J. (2010). The costs of municipal waste and recycling programs. Resources, Conservation and Recycling, 54(11), 864-871. doi: 10.1016/J.RESCONREC.2010.01.005

Burn, S. M. (1991). Social Psychology and the Stimulation of Recycling Behaviors: The Block Leader Approach. Journal of Applied Psychology, 21(8), 611-629. doi: 10.1111/j.1559-1816.1991. tb00539.x

China Daily. (2010, November 26). Classification of trash. Retrieved from http://europe.chinadaily. com.cn/opinion/2010-11/26/content_11613260. htm, on 26 November 2019.

Dinas Kebersihan dan Ruang Terbuka Hijau Kota Surabaya. (2018). Profil Dinas Kebersihan dan Ruang Terbuka Hijau Kota Surabaya Tahun 2018. Surabaya: Dinas Kebersihan dan Ruang Terbuka Hijau Kota Surabaya.

Effendi, Z. (2017, Februari 27). Ini Solusi Pemkot Surabaya Kurangi Sampah Masuk ke TPA dan Pantai. Retrieved from https://m.detik.com/news/ berita-jawa-timur/d-3433330/ini-solusi-pemkotsurabaya-kurangi-sampah-masuk-ke-tpa-danpantai, on 18 November 2019.

Faqih, F. (2019, Juni 13). Pemkot Lelang Hasil Pengumpulan Botol Plastik Suroboyo Bus. Retrieved from https://www.merdeka.com/ peristiwa/pemkot-lelang-hasil-pengumpulanbotol-plastik-suroboyo-bus.html, on 11 Oktober 2019.

Hadi, S. (2019, Agustus 6). Cara Pemkot Surabaya Mengedukasi Warga Dalam Menjaga Lingkungan. Retrieved from https://www. medcom.id/nasional/daerah/GNGjW5dK-carapemkot-surabaya-mengedukasi-warga-dalammenjaga-lingkungan, on 26 November 2019.

Hakim, L.N. (2014). Peran Serta Masyarakat dalam Pengelolaan Sampah, dalam Nurhayati (Ed.), Sampah: Permasalahan dan Pengelolaannya. Jakarta: P3DI Setjen DPR RI dan Azza Grafika.
Hofstede, G. (2011). Dimensionalizing Cultures: The Hofstede Model in Context. Online Readings in Psychology and Culture, 2(1).

Hoornweg, D. \& Bhada-Tata, P. (2012). What A Waste: A Global Review of Solid Waste Management. March 2012, No. 15. Washington: World Bank.

Jayani,D.H.(2019, Agustus,3).MenengokPengelolaan Sampah di Jakarta dan Surabaya. Retrieved from https://katadata.co.id/berita/2019/08/03/ menengok-pengelolaan-sampah-di-jakarta-dansurabaya, on 11 September 2019.

Kementerian Lingkungan Hidup dan Kehutanan. Data Umum Sistem Pengelolaan Sampah Nasional. Retrieved from http://sipsn.menlhk.go.id/?q=3adata-umum\&field_f_wilayah_tid $=1519 \&$ field 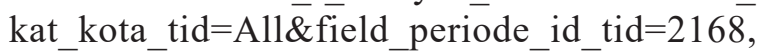 on 11 September 2019.

Kementerian Lingkungan Hidup dan Kehutanan. Penanganan Sampah dan Limbah Plastik serta Pengawasan terhadap Kebijakan Impor Limbah, Tindak Lanjut Pasca COP 24 di Polandia, dan Penanganan Kasus Pasca Tambang. Paparan disampaikan dalam Rapat Kerja Menteri LHK dengan Komisi VII DPR RI, 15 Maret 2019.

Kementerian Pekerjaan Umum. (2010). Modul Pengolahan Sampah Berbasis 3R. Bandung: Kementerian Pekerjaan Umum.

Komunitas Nol Sampah (H). (2019). Kebijakan Pembatasan Sampah Plastik Sekali Pakai dan Implikasinya terhadap Industri dan Masyarakat/ Pewawancara: Tim Peneliti Bidang Kesejahteraan Sosial, Pusat Penelitian Badan Keahlian DPR RI.

Kuo, L. (2019, Juli 12).'A sort of eco-dictatorship': Shanghai grapples with strict new recycling laws. Retrieved from https://www.theguardian.com/ world/2019/jul/12/a-sort-of-eco-dictatorshipshanghai-grapples-with-strict-new-recyclinglaws, on 23 September 2019.

Lestari, N.P. \& Riyanto, D.W.U. (2018). IbM Bank Sampah Desa Mojorejo Kota Batu. MATAPPA: Jurnal Pengabdian Kepada Masyarakat, 1(1), 23-27.

Loka Pengelolaan SD Pesisir \& Laut Sorong. (2018, Juli 24). 2018, 15 Juli. Retrieved from https://kkp. go.id/djprl/lpsplsorong/artikel/5460-tanpamuplastik-alamku-lebih-asyik, on 17 Oktober 2019.

Maulidiya, P. (2018, Februari 21). Komunitas di Surabaya Ini Kirim Puluhan Paket Sampah 
ke Perusahaan-Perusahaan, Ada Apa? Retrieved from https://surabaya.tribunnews. com/2018/02/21/komunitas-di-surabaya-inikirim-puluhan-paket-sampah-ke-perusahaanperusahaan-ada-apa, on 26 November 2019.

Mezghenni, R., \& Zouari, S. (2016). Concern for the Environment in Terms of Waste Sorting Behavior: Concepts and Profiles. SAGE Open, 6(4), 1-8. doi: 10.1177/2158244016657140

Molstad, E., Heyer, K. P., Marttin, K., Sardi, P., Bunnag, A., \& Wattanaburanon, A. (2018). Reducing Single-Use Plastic in a Thai School Community: A Sociocultural Investigation in Bangkok, Thailand Reducing Single-Use Plastic in a Thai School Community A Sociocultural Investigation in Bangkok, Thailand. A Sociocultural Investigation in Bangkok, Thailand, (February), 1-75. Retrieved from https:// digitalcommons.wpi.edu/iqp-all\%0ARepository.

Octovie, D. (2019, Februari 3) Komunitas SeaSoldier Kumpulkan 1 Ton Sampah dari TamanTaman Kota Surabaya, Prihatin Prilaku Warga, Retrieved from https://surabaya.tribunnews. com/2019/02/23/komunitas-seasoldierkumpulkan-1-ton-sampah-dari-taman-tamankota-surabaya-prihatin-prilaku-warga, on 25 November 2019.

Pembina BSIS (AN). (2019). Kebijakan Pembatasan Sampah Plastik Sekali Pakai dan Implikasinya terhadap Industri dan Masyarakat/Pewawancara: Tim Peneliti Bidang Kesejahteraan Sosial, Pusat Penelitian Badan Keahlian DPR RI.

Pemerintah Kota Surabaya. Peraturan Walikota Surabaya Nomor 27 Tahun 2018 tentang Rencana Kerja Pemerintah Daerah (RKPD) Kota Surabaya Tahun 2019 (2019).

Prasetiawan, T. (2014). Peluang Implementasi Extended Producer Responsibility (EPR) di Indonesia, dalam Nurhayati (Ed.), Sampah: Permasalahan dan Pengelolaannya. Jakarta: P3DI Setjen DPR RI dan Azza Grafika.

Rukmananda, N. (2017, November 1). Kota Surabaya Raih Penghargaan 'Global Green City' PBB, Retrieved from https://www.voaindonesia. com/a/kota-surabaya-raih-penghargaan-globalgreen-city-pbb/4095316.html, on 20 November 2019.

Schumaker, E. (2016, Agustus 3). The Psychology Behind Why People Don't Recycle. Retrieved from https://www.huffpost.com/entry/ psychology-of-why-people-dont-recycle_n_5
$7697 \mathrm{a} 7 \mathrm{be} 4 \mathrm{~b} 087 \mathrm{~b} 70 \mathrm{be} 605 \mathrm{~b} 3$, on 11 September 2019.

Schultz, P. W., Bator, R. J., Large, L. B., Bruni, C. M., \& Tabanico, J. J. (2013). Littering in Context: Personal and Environmental Predictors of Littering Behavior. Environment and Behavior, 45(1), 35-59. doi: 10.1177/0013916511412179

Sita E-KTP bagi Pembuang Sampah. (2018, July 15). Jawa Pos.

Soewardi, H., S. Sari, A.D., dan Aktoba, R. (2017). Ergonomic Participatory Approach for Designing the Innovative Trash Bin. International Journal of Applied Engineering Research, 12(12) 2017, 14510-14513.

Sukerti, N. L. G., Sudarma, I. M., \& Pujaastawa, I. B. (2017). Perilaku Masyarakat Dalam Pengelolaan Sampah Dan Faktor-Faktor Yang Mempengaruhi Di Kecamatan Denpasar Timur Kota Denpasar, Provinsi Bali. ECOTROPHIC: Jurnal Ilmu Lingkungan (Journal of Environmental Science), 11(2), 148. doi: 10.24843/ejes.2017.v11.i02.p05

Tanuwijaya, F. (2016). Partisipasi Masyarakat Dalam Pengelolaan Sampah di Bank Sampah Pitoe Jambangan Kota Surabaya. Kebijakan dan Manajemen Publik, 4(2) Mei-Agustus 2016, 230-244. Retrieved from http://journal.unair. ac.id/download-fullpapers-kmpbc2c70fe31 full. pdf, on 26 November 2019.

Xu, L., Ling, M., Lu, Y., \& Shen, M. (2017). Understanding household waste separation behaviour: Testing the roles of moral, past experience, and perceived policy effectiveness within the theory of planned behaviour. Sustainability, 9(4), 1-27. doi: 10.3390/ su9040625

Wu, D.W.-L., Lenkic, P. J., DiGiacomo, A., Cech, P., Zhao, J., \& Kingstone, A. (2018). How does the design of waste disposal signage influence waste disposal behavior? Journal of Environmental Psychology, 58(2018), 77-85. doi: 10.1016/j. jenvp.2018.07.009

Zakianis, S., \& Djaja, I. M. (2017). The Importance of Waste Management Knowledge to Encourage Household Waste-Sorting Behaviour in Indonesia. International Journal of Waste Resources, 07(04). doi: 10.4172/2252-5211.1000309 